\title{
Sedimentary successions in the Middle-Upper Oxfordian reef deposits from the southern part of the Kraków-Częstochowa Upland (Southern Poland)
}

\author{
Marcin KRAJEWSKI ${ }^{1, *}$, Piotr OLCHOWY ${ }^{1}$ and Damian RUDZIŃSKI ${ }^{1}$ \\ 1 Faculty of Geology, Geophysics and Environmental Protection, AGH University of Science and Technology, \\ al. A. Mickiewicza 30, 30-059 Kraków, Poland
}

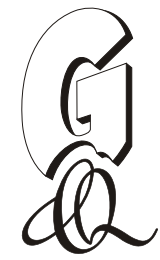

\begin{abstract}
Krajewski, M., Olchowy, P., Rudziński, D., 2018. Sedimentary successions in the Middle-Upper Oxfordian reef deposits from the southern part of the Kraków-Częstochowa Upland (Southern Poland). Geological Quarterly, 62 (3): 653-668, doi: 10.7306/gq.1429

The sedimentary succession of the largest example of an Upper Oxfordian reef located in the southern part of the Polish sector of the northern Tethys shelf is described. Detailed sampling of exposures enabled characterization of the full succession of facies and microfacies diversity, documenting the reef evolution. The succession studied represents the maximum development of Upper Jurassic reefs in Poland corresponding to the upper Transversarium and the Bifurcatus zones, and followed by drowning of the carbonate platform in the lower Bimmamatum Zone. The reef succession comprises three types of facies, in which eight important microfacies types were distingushed, reflecting several stages of reef development. Mid-ramp, microbial-sponge frame-reefs represent a transgressive depositional sequence, up to tens of metres thick. A microbial-Crescentiella-ooid and ooid-intraclast-bioclast facies form numerous, decimetre- to metre-scale, sequences corresponding to higher-order, transgressive/regressive sea level changes. These facies represent a mid-inner ramp setting when sedimentation was dominated by bioclasts and non-skeletal grains (mainly ooids, oncoids, aggregate grains and intraclasts). The grains were stabilized by microbialites and cemented in early diagenesis, which created grain-dominated, microbial-cement supported reefs. As a result, both the mid-ramp, microbial-sponge frame-reefs and the shallow-water, grain-dominated, microbial-cement supported reefs form extensive, strongly lithified Oxfordian reef complexes in the Kraków-Częstochowa Upland.
\end{abstract}

Key words: microbialites, non-skeletal grains, reef, carbonate ramp, Oxfordian, Poland.

\section{INTRODUCTION}

The most characteristic features of the Kraków-Częstochowa Upland (KCU), also named the "Polish Jura", are the Upper Jurassic white rocks, forming vertical cliffs, which represent various types of Oxfordian reefs (Fig. 1A). In the KCU landscape, the reefs form several NW-SE-trending ranges dominated by hard, reefal massive facies, which, together with biostromal thick-bedded facies build extensive reef complexes (e.g., Dżułyński, 1952; Matyszkiewicz, 1997; Matyszkiewicz et al., 2006a, b, 2015a). The Oxfordian reefs extend to the SE, in the basement of the Carpathian Foredeep (Morycowa and Moryc, 1976; Król, 2004; Matyja, 2009; Krajewski et al., 2011). In the Polish part of the Tethys shelf, the carbonate buildups started to grow at the beginning of the Middle Oxfordian (Fig. 2) as small, sponge and sponge-microbial, low-relief, spaced cluster reefs (sensu Riding, 2002) without rigid frameworks (e.g. Dżułyński, 1952; Trammer, 1982; Matyszkiewicz et al., 2012, 2015b). These buildups evolved in time into the Late Oxfordian

* Corresponding author, e-mail: kramar@geol.agh.edu.pl

Received: April 13, 2018; accepted: May 26, 2018; first published online: September 21, 2018 as: (1) sponge-microbial segment-reefs with laminar frameworks, (2) sponge-microbial filled frame-reefs with initial, reticulate rigid frameworks, which, in turn, were later replaced by (3) microbial-sponge or microbial-Crescentiella open frame-reefs with well-developed reticulate rigid frameworks and common stromatactis-like cavities (e.g., Trammer, 1989; Matyszkiewicz, 1997; Krajewski, 2000; Matyszkiewicz et al., 2006a, 2012, 2015a, b; Olchowy, 2011). These reefs are built mostly or in places even entirely of grainstones stabilized by microbial structures and contain only small amounts of metazoans.

The most spectacular Upper Jurassic reefs encountered in the Polish sector of the northern Tethys shelf crop out $\sim 25 \mathrm{~km}$ to the NW of Kraków, in the Prądnik River Valley (the Ojców National Park) and in the Będkowska Valley (Fig. 1). In the Będkowska Valley two varieties of carbonate buildups occur: (1) microbial-sponge, and (2) numerous, small microbial-Crescentiella (originally microbial-Tubiphytes) bioherms (Krajewski, 2000; Krajewski and Matyszkiewicz, 2004).

Despite the long research history of Oxfordian reefs in both the extensive northern shelf of the Tethys Ocean (e.g., Gwinner, 1976; Gaillard, 1983; Keupp et al., 1993; Koch et al., 1994, Leinfelder et al., 1994, 1996; Leinfelder and Keupp, 1995; Helm and Schülke, 1998; Dupraz and Strasser, 1999; Schmid et al., 2001; Olivier et al., 2003; Olóriz et al., 2003; Reolid et al., 2005; Reolid and Gaillard, 2007 and refferences therein) and the KCU (e.g., Dżułyński, 1952; Roniewicz and 


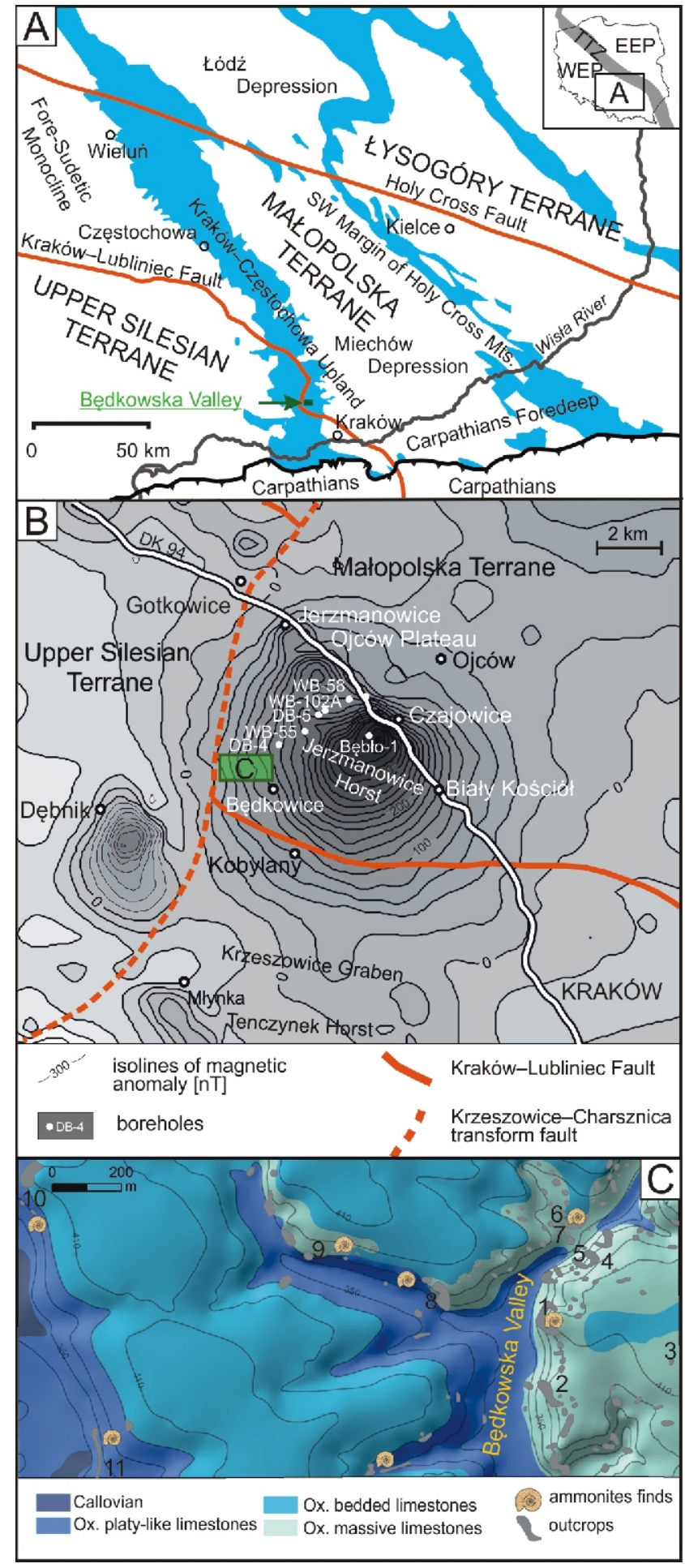

Fig. 1. Location of the study area

A - location map of the study areas with Upper Jurassic outcrops and sub-Cenozoic Jurassic subcrops (blue) in southern and central Poland after Pożaryski et al., (1979), modified and simplified; tectonic structures (red) after Żelaźniewicz et al. (2011); TTZ Teisseyre-Tornquist Zone, EEP - East European Platform, WEP West European Platform; B - location of the Ojców Plateau on the $\Delta \mathrm{T}$ magnetic anomaly map (modified after Jędrys and Krajewski, 2007) and the main tectonic structures after Żelaźniewicz et al. (2011); green rectangle indicates study area shown on Fig. 1C; C map of the Oxfordian facies; after Krajewski and Matyszkiewicz (2004, modified) with investigated exposures; 1 - Sokolica, 2 Wysoka, 3 - Będkowice Quarry, 4 - Cmentarzysko, 5 - Iglica, 6 Dupa Słonia; 7 - Turnia Lipczyńskiej; 8 - Brandysowa, 9 Przecówki, 10 - Brodło, 11 - Szklary Quarry
Roniewicz, 1971; Trammer, 1982, 1989; Matyszkiewicz and Felisiak, 1992; Matyszkiewicz and Krajewski, 1996; Matyszkiewicz, 1997; Krajewski, 2000; Matyszkiewicz et al., 2006a, b, 2012; Kochman and Matyszkiewicz, 2013; Matyszkiewicz and Kochman, 2016), the detailed sedimentary succession of the main phase of reef growth in Poland has not been fully recognized up to now for many reasons, e.g.: (1) limited accessibility influencing the macroscopic observations, (2) apparently monotonous macroscopic facies and (3) only few successions being subjected to detailed microfacies analysis. This paper presents data gathered from new logs, which allow for a more detailed reconstruction of the growth stages of the Upper Oxfordian reefs in the southern part of the KCU.

\section{UPPER JURASSIC SEDIMENTARY SUCCESSION AND FACTORS CONTROLLING DEPOSITION IN THE KRAKÓW-CZĘSTOCHOWA UPLAND}

The KCU is a part of the Silesian-Kraków Homocline built of Triassic, Middle-Upper Jurassic and Upper Cretaceous, mainly carbonate strata that dip gently to the NE. The maximum thickness of Upper Jurassic deposits in the Kraków area is $\sim 250 \mathrm{~m}$ (Fig. 2). The Upper Jurassic succession begins with Lower Oxfordian and Lower-Middle Oxfordian thin-bedded marls alternating with marly limestones (Fig. 2). These strata grade upwards into strongly differentiated, Middle Oxfordian-Lower Kimmeridgian massive and thick-bedded limestones with flints (Fig. 2). The topmost, Lower Kimmeridgian part of the succession comprises thin-bedded limestones and marls. In the Upper Jurassic succession of southern Poland, three episodes related to synsedimentary tectonic events have been identified in the following zones: (1) Transversarium, (2) lower Bimammatum and (3) Platynota (Fig. 2). During these episodes, breaks in reef growth occurred enabling the development of gravity-flow deposits (debrites, calciturbidites, olistoliths) and neptunian dykes (e.g., Matyszkiewicz, 1997; Matyszkiewicz et al., 2006a, 2012, 2016; Ziółkowski, 2007; Barski and Mieszkowski, 2014; Brachaniec et al., 2016; Woźniak et al., 2018).

The Polish part of the carbonate platform is commonly classified as a carbonate ramp (e.g., Kutek, 1994; Gutowski et al., 2005; Krajewski et al., 2011a, 2016) or an open shelf (e.g., Matyja et al., 1989). The main controlling factors of platform evolution were: (1) sea level changes, (2) synsedimentary tectonics and (3) Paleozoic basement elevations (e.g., Kutek, 1994; Matyszkiewicz, 1997; Gutowski et al., 2005; Matyszkiewicz et al., 2006a, b, 2012, 2016; Barski and Mieszkowski, 2014; Krajewski et al., 2014, 2016, 2017; Wierzbowski, 2017; Woźniak et al., 2018). Particularly important factors, which periodically modified the sea-bottom morphology and the palaeoenvironmental conditions, were extensional tectonic movements (Kutek, 1994; Matyszkiewicz, 1997; Krajewski et al., 2016; Matyszkiewicz et al., 2016). The KCU area occupies the border zone of large, Paleozoic, regional tectonic units: the Małopolska and the Upper Silesian terranes (Fig. 1A and B). The synsedimentary tectonics, related to rejuvenation of Paleozoic structures (e.g., Żaba, 1999), caused periodic breakup of the carbonate platform into many smaller, fault-controlled intra-platform ridges and basins (e.g., Matyszkiewicz et al., 2006a, 2012; Krajewski et al., 2016, 2017). These ridges and basins, located at the contact of the Upper Silesian and Małopolska terranes, may have resulted from NE-trending progradation of the rifting process from the southern areas towards the northern Tethys shelf. The opening of the North Atlantic and Tethys Oceans resulted in the Late Jurassic reorganization of the stress field, which affected also the passive, northern margin of the Tethys (e.g., Ziegler, 1990; Allenbach, 
Kraków Upland

Fore-Sudetic Homocline

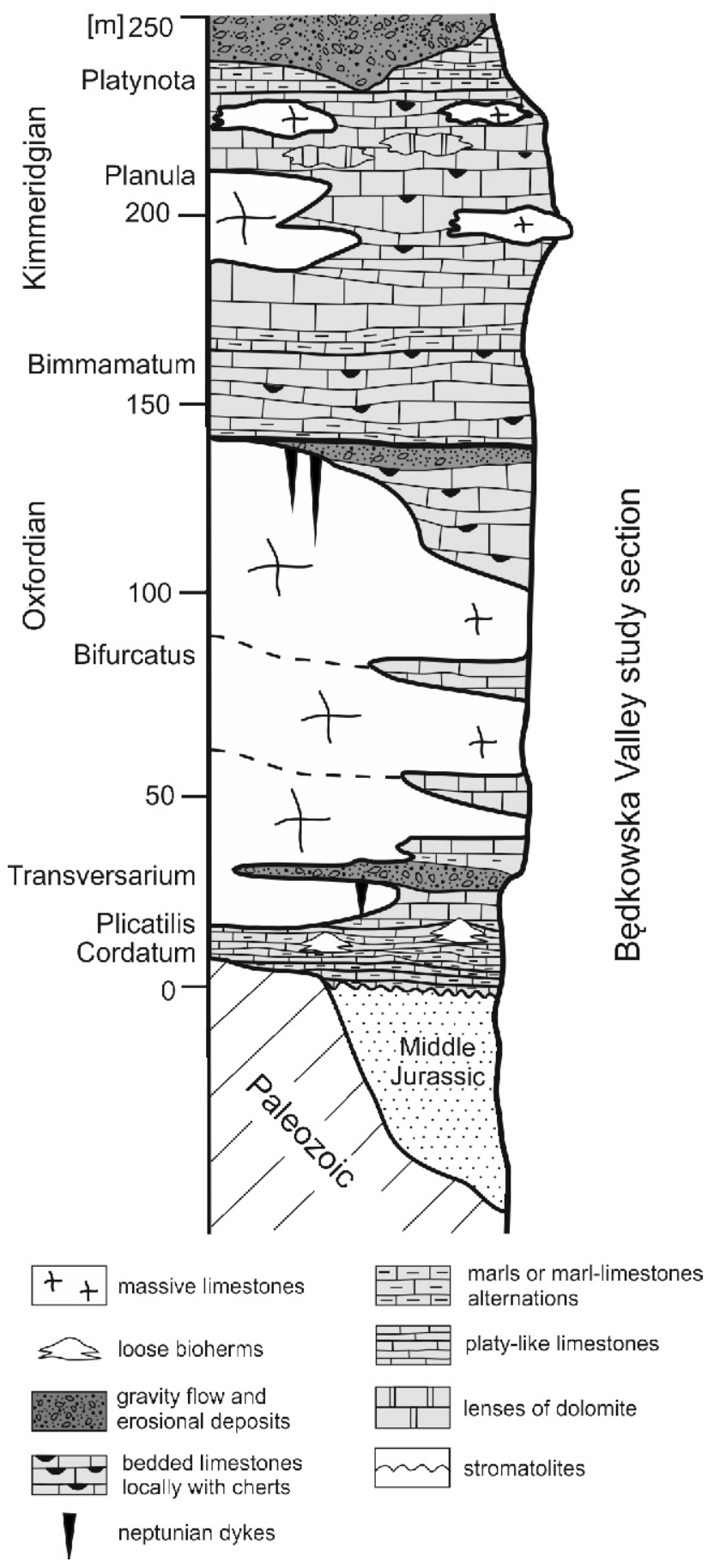

Fig. 2. Lithostratigraphic column of Upper Jurassic strata in the southern part of the Kraków-Częstochowa Upland with the stratigraphic position of the sedimentary succession from Będkowska Valley (after Matyszkiewicz et al., 2016, modified)

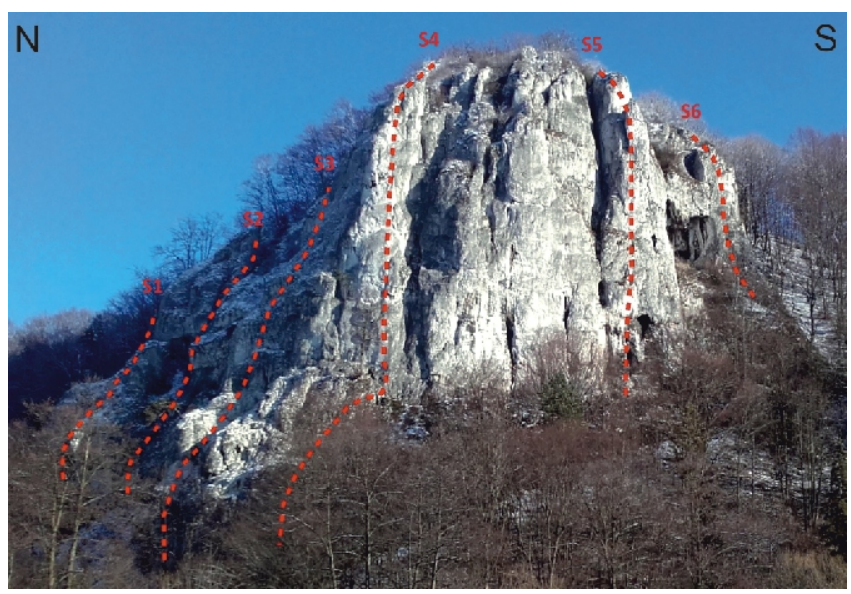

Fig. 3. Sokolica Rock, location of the logs studied (dotted red lines), western slope, height of rock $\sim 80 \mathrm{~m}$

2002; Nieto et al., 2012; Krajewski et al., 2016; Matyszkiewicz et al., 2016).

\section{MATERIALS AND METHODS}

The detailed sedimentological observations were carried out on the Sokolica Rock located in the central part of the Będkowska Valley (Figs. 1C and 3). The Sokolica Rock is the largest exposure of Oxfordian massive reef facies in Poland. The main face of the Sokolica Rock is up to $80 \mathrm{~m}$ high. In order to reconstruct both the vertical and the lateral development of the facies, six vertical logs were established using climbing techniques (Fig. 3). Along these lines variability of facies development was noted and samples were collected for polished sections and laboratory analyses: microfacies observations and cathodoluminescence studies $(\mathrm{CL})$ in thin section. CL observations were carried out using a cold-stage cathodoluminescence microscope CLmk3A of CIT Ltd., coupled with the Nikon Eclipse 50T. The accelerating voltage was $15-17 \mathrm{kV}$ and the electron-beam intensity 450-500 $\mu \mathrm{A}$. Moreover, microfacies analysis was also carried on adjacent exposures: Brodło, Iglica, Cmentarzysko, Dupa Słonia, Przecówki, Wysoka and Brandysowa rocks as well as in the Będkowice Quarry (Fig. 1C; Krajewski and Matyszkiewicz, 2004), in order to see whether the facies identified in the Sokolica Rock extend laterally.

\section{RESULTS}

\section{OXFORDIAN SEDIMENTARY SUCCESSION OF THE STUDY AREA}

The basement of the study area is built of Cambrian deposits intruded by Permian granitoids which form the Będkowska Valley batholith underlying the Ojców Plateau (Fig. 1B; e.g., Harańczyk et al., 1995; Żaba, 1999; Żeleźniewicz et al., 2011). The top surface of the Paleozoic basement is located a few metres beneath the Callovian/Oxfordian boundary, which is a transregional condensed horizon with yellow or red stromatolitic structure (Fig. 2; e.g., Matyszkiewicz et al., 2015b). Above, we observe Lower and Middle Oxfordian marls, sponge-bearing marly limestones and thin-bedded bioclastic limestones (locally named "platy limestones"; e.g., Dżułyński, 1952) with an abundant ammonite fauna and a total thickness of up to a dozen metres in the Kraków area (e.g., Matyja and Tarkowski, 1981; 
Głowniak, 2006; Jurkowska and Kołodziej, 2013). These deposits grade both vertically and laterally into the Upper Oxfordian white, massive or, rarely, pseudonodular limestones defined as a rock composed of densely packed, connected rounded-oval to subangular nodules (see Matyszkiewicz and Kochman, 2016). In the Będkowska Valley, the thickness of massive limestones reaches $120 \mathrm{~m}$ whereas the thickness of the whole Upper Jurassic sedimentary succession in the study area is up to $150 \mathrm{~m}$, which constitutes more than half of total thickness of this unit in the Kraków area (Fig. 2). The top part of the Upper Jurassic sedimentary succession in the study area comprises bioclastic, medium- and thin-bedded limestones with flints, intercalated with marly limestones and marls, all accessible in a few exposures or small quarries scattered across the Ojców Plateau.

\section{STRATIGRAPHY}

The stratigraphy of the Upper Jurassic deposits in the study area is based upon ammonites (Krajewski, 2000; Krajewski and Matyszkiewicz, 2004; Fig. 1C). In the bottom part of the succession, a several-metres-thick unit of marls and sponge-marly limestones represents the Lower and Middle Oxfordian in the Kraków area (Cordatum-Plicatilis zones; e.g., Matyja and Tarkowski, 1981; Głowniak, 2006; Fig. 2). Upwards thin-bedded limestones (platy limestones) appear, representing the Transversarium Zone. In these limestones, Perisphinctes (Dichotomosphinctes) dobrogensis Simonescu indicative of the Buckmani Subzone was found, together with Subdiscosphinctes sp. Malinowska and Perisphinctes (Dichotomosphinctes) elisabethae de Riaz representing the Elisabethae Subzone of the upper Transversarium Zone as well as Perisphinctes (Dichotomoceras) wartae Bukowski from the Wartae Subzone of the Bifurcatus Zone (Krajewski and Matyszkiewicz, 2004; E. Głowniak, pers. com., 2000). The massive limestones observed in the lowermost part of the succession also represent the upper part of the Transversarium Zone or the lower part of the Bifurcatus Zone (Krajewski, 2000; Fig. 2). The ammonite encountered in the central part of the Sokolica Rock is Perisphinctes (Dichotomoceras) cf. bifurcatoides Enay, which indicates the Stenocycloides Subzone, i.e. the upper part of the Bifurcatus Zone (Krajewski, 2000; B.A. Matyja, pers. com., 1998). The massive limestones are covered with bioclastic bedded limestones with flints intercalated with marls and marly limestones. Over the Ojców Plateau, these carbonates are dated at the HypselumBimammatum Subzone of the Bimmamatum Zone (Ziółkowski, 2007; Fig. 2).

\section{FACIES, MICROFACIES AND SEDIMENTARY SUCCESSIONS} OF THE SOKOLICA ROCK

In the Sokolica Rock sedimentary succession, three facies types (FT 1, 2, 3; Fig. 4) were distinguished: (1) microbial-sponge (FT 1), (2) microbial-Crescentiella-ooid (FT 2) and (3) ooid-intraclast-bioclastic (FT 3). Comparative observations made in the vicinity of the Sokolica Rock (Fig. 1C) indicated a similar facies and microfacies succession. Hence, it is assumed that the sedimentary succession of the Sokolica Rock can be proposed as representative for other reef complexes in the southern part of the KCU. In these facies, eight microfacies types were identified (MT I-VIII; Figs. 4-11). Comparison of microfacies development and variability in the Sokolica Rock succession with the adjacent exposures enables us to suggest

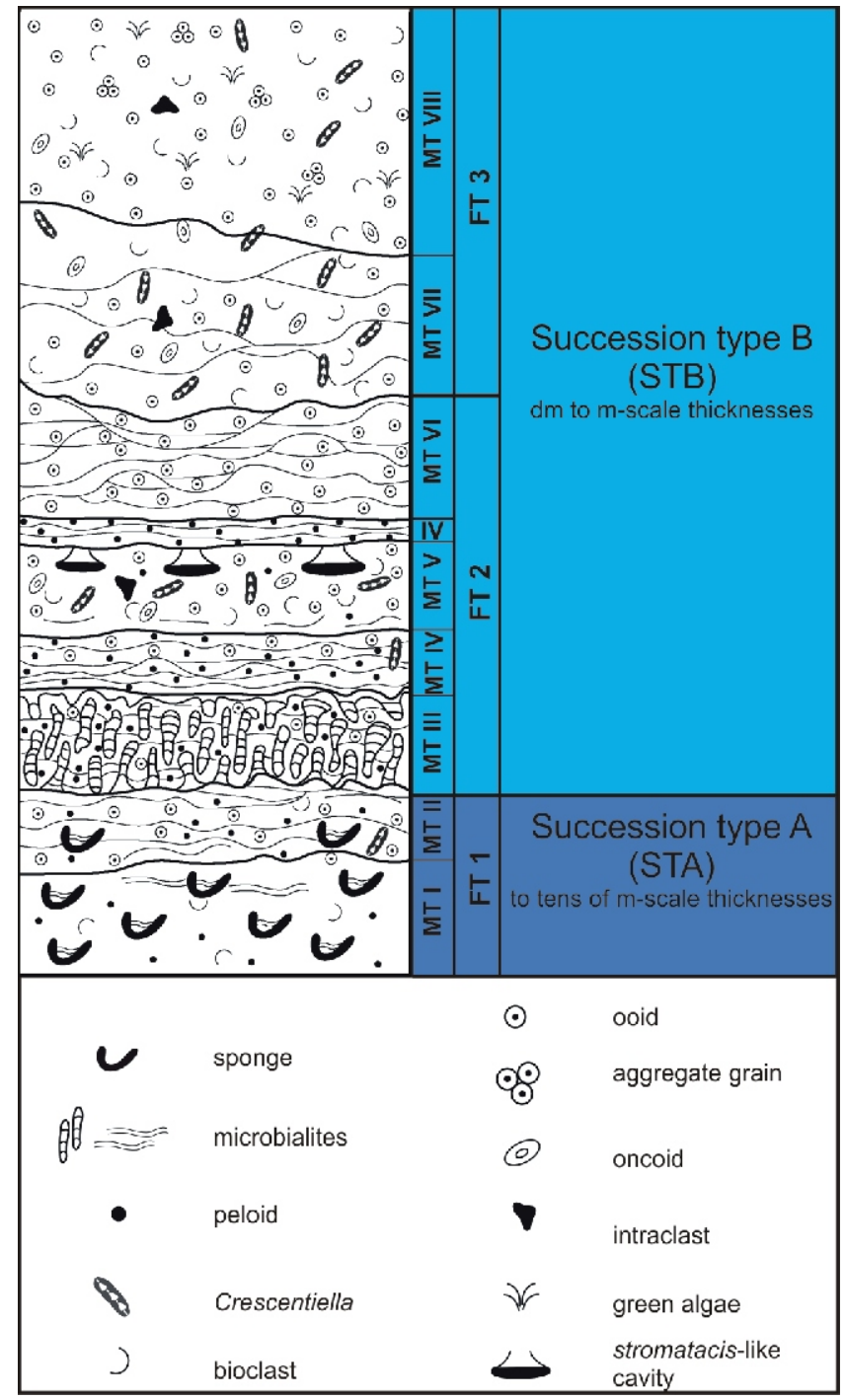

Fig. 4. Microfacies types (MT), facies types (FT) and sedimentary successions of the massive facies of the Będkowska Valley

that these facies form characteristic stratigraphic intervals of significant lateral extent (Fig. 5).

The vertical facies transitions are gradual although usually observed within a decimetre. The FT 1/FT 2, 3 transition is not confined to the same level, which reflects a diverse relief of the microbial-sponge reef during its growth (Fig. 5). By contrast, the FT 2, 3/FT 1 transitions observed higher in the succession occur at the same levels across the Sokolica Rock (Fig. 5). The abundant sponges observed in the FT 1 facies allow for macroscopic distinguishing of this type from both the FT 2 and FT 3 types, which are dominated by microbialites and non-skeletal grains. Thicknesses of the FT 1 type vary from several to a dozen metres (Fig. 5). Due to intense cementation resulting in the massive structure of the limestones and the cyclicity of sedimentary sequences, the FT 2 and FT 3 types are difficult to identify macroscopically (Figs. 3 and 5). Moreover, some parts of the limestones were subjected to silicification. In places, the FT 1/FT 2, 3 boundaries are marked by synsedimentary breccias, which document distinct erosional episodes causing breaks in reef growth. The breccias are several tens of centime- 


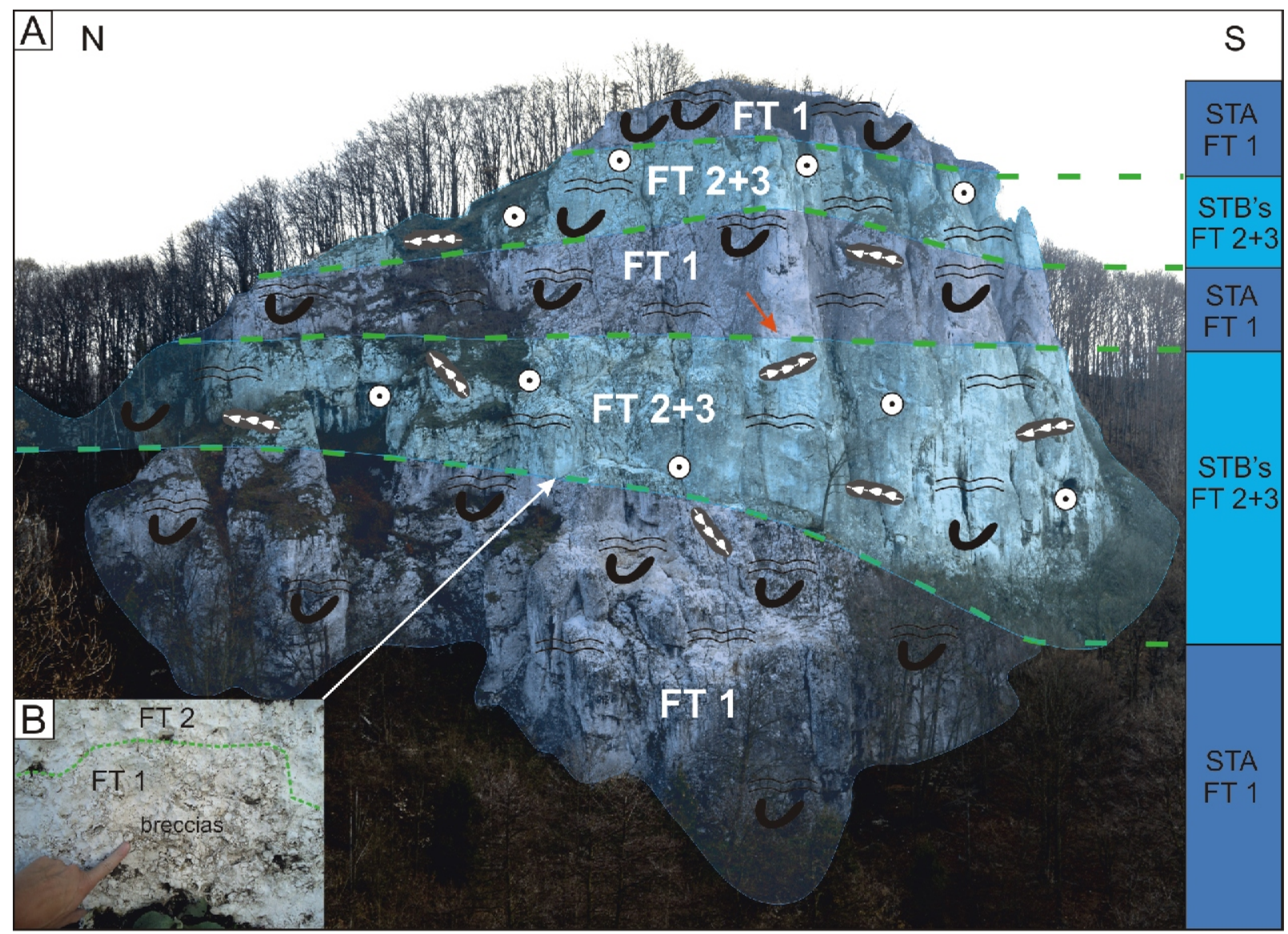

Fig. 5A - distribution of the facies (FT 1 and FT 2+3) in the sedimentary succession of Sokolica Rock, red arrow indicates ammonite find; B - breccias observed in the central part of Sokolica Rock

Explanations as in Figure 4

ters thick and are composed of angular to subangular clasts of FT 1 (Fig. 5B).

Based upon the facies, two sedimentary succession types were distinguished in the Sokolica Rock: (1) succession type A (STA) composed by FT 1 facies and (2) succession type B (STB) composed by FT 2 and FT 3 facies (Figs. 4 and 5).

\section{SUCCESSION TYPE A (STA)}

FT 1: microbial-sponge facies. This facies dominates in three stratigraphic intervals up to $30 \mathrm{~m}$ thick in the lowermost part of the Sokolica Rock (Fig. 5). Within these intervals, the FT 1 facies does not reveal essential changes in development - it comprises generations of calcified siliceous sponges forming so-called "unitary sedimentary sequences", overgrowing one another. The unitary sedimentary sequences are built of sponges together with the encrusting epifauna, microbialites growing on top of the sponges and bioclastic-micritic wackestones-packstones filling the intraframework spaces (Figs. 6A, B and 7A-C). The FT 1 type includes two microfacies types: (1) sponge-microbial floatstone-framestone (MT I; Figs. 6A and 7A) and (2) microbial-sponge framestone (MT II; Figs. 4 and 6B, C). Basically, the MT I microfacies is formed mainly of consecutive generations of dish-shaped, calcified siliceous sponges (Lithistida and Hexactinellida) onto which clotted thrombolites and micritic stromatolites (cf. Schmid, 1996; Riding, 2000, 2002) are deposited (Figs. 6A and 7A, B). The intraframework spaces are filled with fine-grained bioclastic wackestones or floatstones or, rarely, packstones composed mostly of peloids, tuberoids, brachiopods, spicules and numerous small bioclasts (Figs. 6A and 7A). Layered leiolites are also common. Apart from microbialites and sponges, microencrusting organisms are abundant, usually bryozoans, benthic foraminifers (Nubecularia, Bullopora), serpulids and agglutinating annelids Terebella lapilloides. Locally, in the lower part of the Sokolica Rock succession, one can observe the FT 1 facies developed as pseudonodular limestones forming metre-scale, nest-like bodies within the massive limestones. The pseudonodular limestones consist of rounded nodules contacting each other along the stylolites (e.g., Matyszkiewicz and Kochman, 2016). Most FT 1 facies intervals are dominated by microbial-sponge framestone (MT II) with prevailing layered and clotted thrombolites and peloidal stromatolites developed on the sponges and within the intraframework spaces (Figs. 4, 6B and 7C). In the upper parts of FT 1 intervals, the MT II microfacies shows increasing amounts of non-skeletal grains. In such cases, both the sponges and the microbialites are covered by packstone-, rarely grainstone-type detritus composed of small (up to $0.6 \mathrm{~mm}$ ), mostly micritized ooids, intraclasts and bioclasts (Fig. 7C). In some lower parts of the reefs, larger amounts of redeposited grains caused periodical breaks in the reef growth (Krajewski, 2000; Krajewski and Matyszkiewicz, 2004).

Facies interpretation: the sponge-microbial and microbial-sponge facies (FT 1) is widely distributed over the whole northern shelf of the Tethys Ocean (see e.g., Keupp et al., 1993; Leinfelder et al., 1994, 1996; Matyszkiewicz, 1997; 

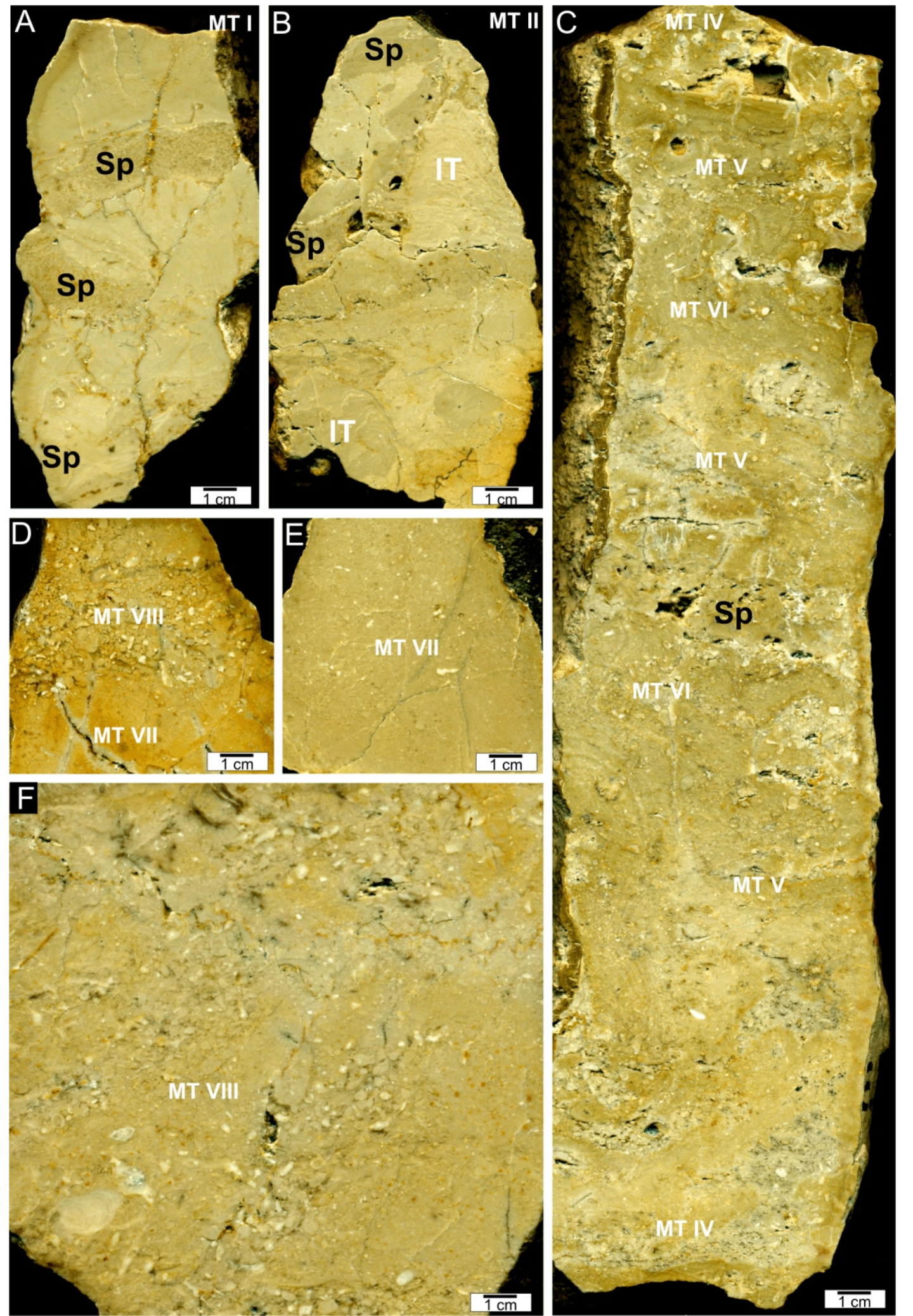

Mit $\mathrm{V}$
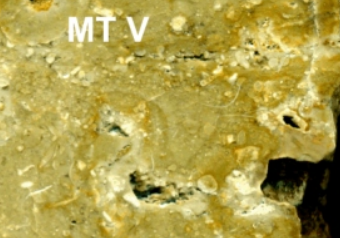

MT VP $\& 0$
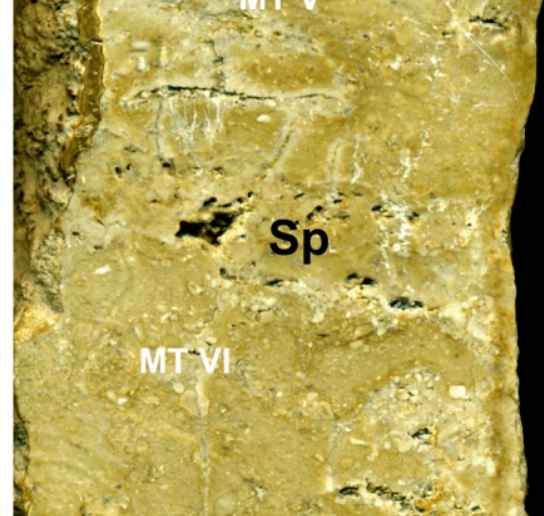

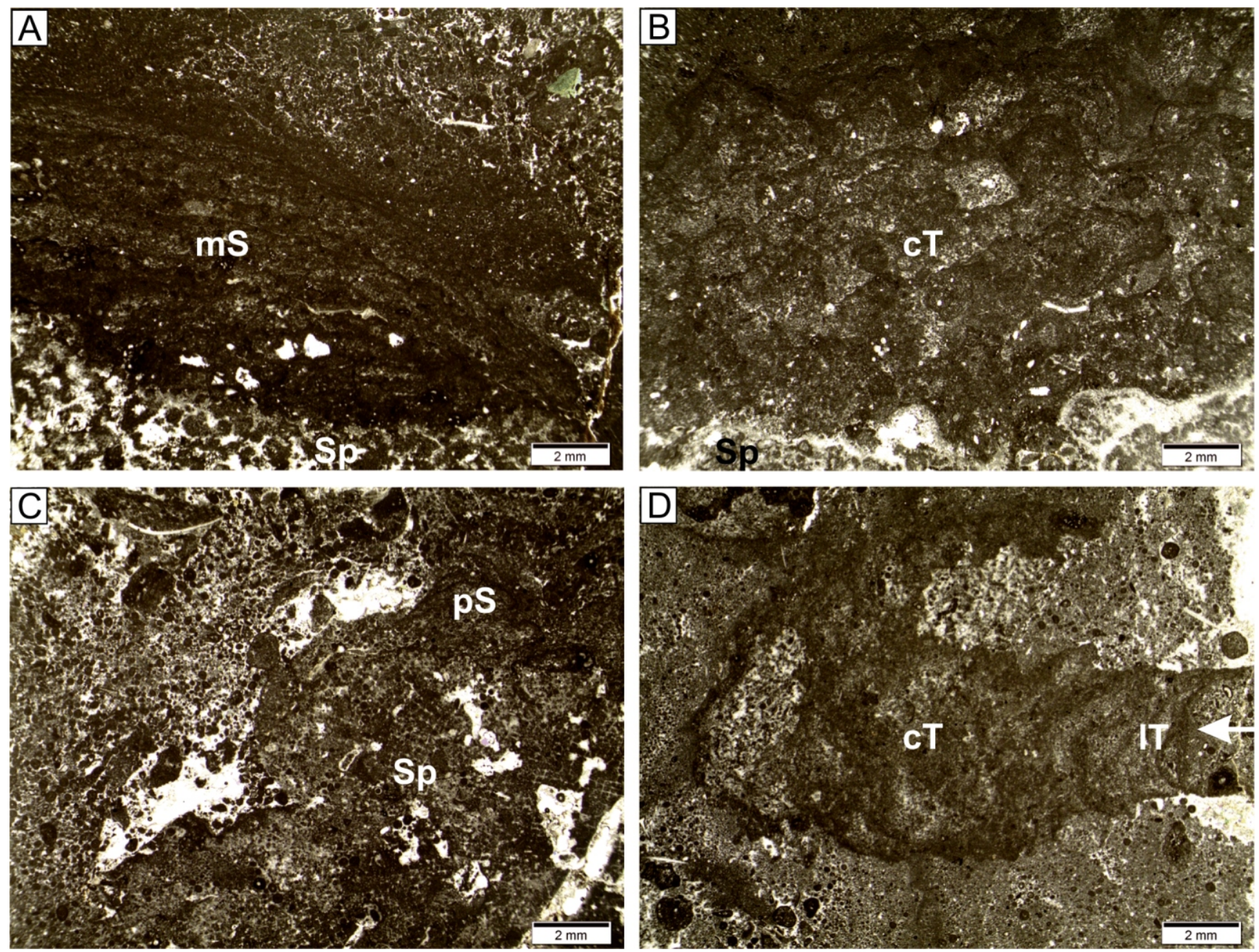

Fig. 7. Microfacies in the Oxfordian reefs from Będkowska Valley

A - sponge-microbial floatstone; in the lower part sponge ( $\mathrm{Sp}$ ) with micritic stromatolite (mS) on the upper surface, MT I, FT 1, sample SN 20; B - microbial-sponge framestone; in the lower part sponge (Sp) and clotted thrombolite (cT) on its upper surface and inter-skeletal spaces, MT II, FT 1, sample Bł 4; C - microbial sponge framestone, siliciceous sponge (Sp) and peloidal stromatolite (pS) on the right, in the upper part peloidal-bioclastic wackestone/packstone, MT II, upper interval of FT 1, sample SN 5; D - thrombolitic bindstone, column of layered (in the lower part) thrombolite (IT) and clotted (in the upper part) thrombolite (cT), the white arrow indicates the orientation of the sample, MT III, FT 2, sample SS 11

Schmid et al., 2001; Olóriz et al., 2003; Olivier et al., 2003 Reolid et al., 2005). FT 1 is interpreted as representing a distal, mid-ramp facies, mostly a low-energy, nutrient-rich environment (e.g., Keupp et al., 1993; Leinfelder et al., 1994, 1996; Olóriz et al., 2003; Olivier et al., 2003) between the fairweather and the storm wave bases, the latter estimated in the northern Tethys shelf as some tens of metres (e.g., Leinfelder et al., 1996; Matyszkiewicz et al., 2006a; Krajewski et al., 2016). Common microencrusters, mostly benthic microbial communities, bryozoans, serpulids, and foraminifers, indicate a low-energy environment, low sedimentation rate and low terrigenous influx (e.g., Reolid and Gaillard, 2007). Terebella lapilloides is commonly observed in Upper Jurassic reefs and indicates a low-energy setting under dysoxic conditions (e.g., Reolid et al., 2005; Kaya and Altiner, 2014).

\section{SUCCESSION TYPE B (STB)}

FT 2: microbial-Crescentiella-ooid facies. This facies type is observed in the stratigraphic intervals above those occupied by the FT 1 facies (Figs. 4 and 5). Both the FT 2 and FT 3 facies comprise numerous, mainly dm-scale sedimentary units (Fig. 6C). Hence, because of the large-scale, strong lithification, it is difficult to precisely identify the boundaries between the FT 2 and FT 3 facies across the entire Sokolica Rock. Consequently, both facies types remain undivided and are shown as one interval (FT 2+3 in Fig. 5). The rare metazoans are represented by calcified siliciceous sponges and calcareous sclerosponges (Fig. 6C). Generally, the FT 2 facies consists of detrital sediments commonly bound by various types of microbialites (Figs. 4 and 6C). Several microfacies types (MT $\mathrm{III}-\mathrm{VI}$ ) can be observed in the vertical succession, gradually replacing each other: (1) thrombolitic bindstone (MT III), (2) peloidal stromatolite bindstone (MT IV), (3) ooid-Crescentiella-bioclastic grainstone-packstone (MT V) and (4) agglutinating stromatolite bindstone (MT VI; Fig. 4). Thicknesses of particular microfacies types range from $\sim 10$ centimetres to (rarely) $\sim 1 \mathrm{~m}$

The MT III microfacies (Figs. 7D and 8A, B) comprises thrombolites representing two morphological varieties: (1) finger-like columnar and (2), less commonly, dome-shaped, layered and poorly structured, all forming horizons up to several tens of centimetres thick (cf. Schmid et al., 2001). Individual thrombolite columns (Fig. 8A, B) are up to $\sim 3 \mathrm{~cm}$ wide and up to $\sim 8 \mathrm{~cm}$ high. Spaces between the columns are filled with allochthonous grains: peloids, small micritic ooids, 


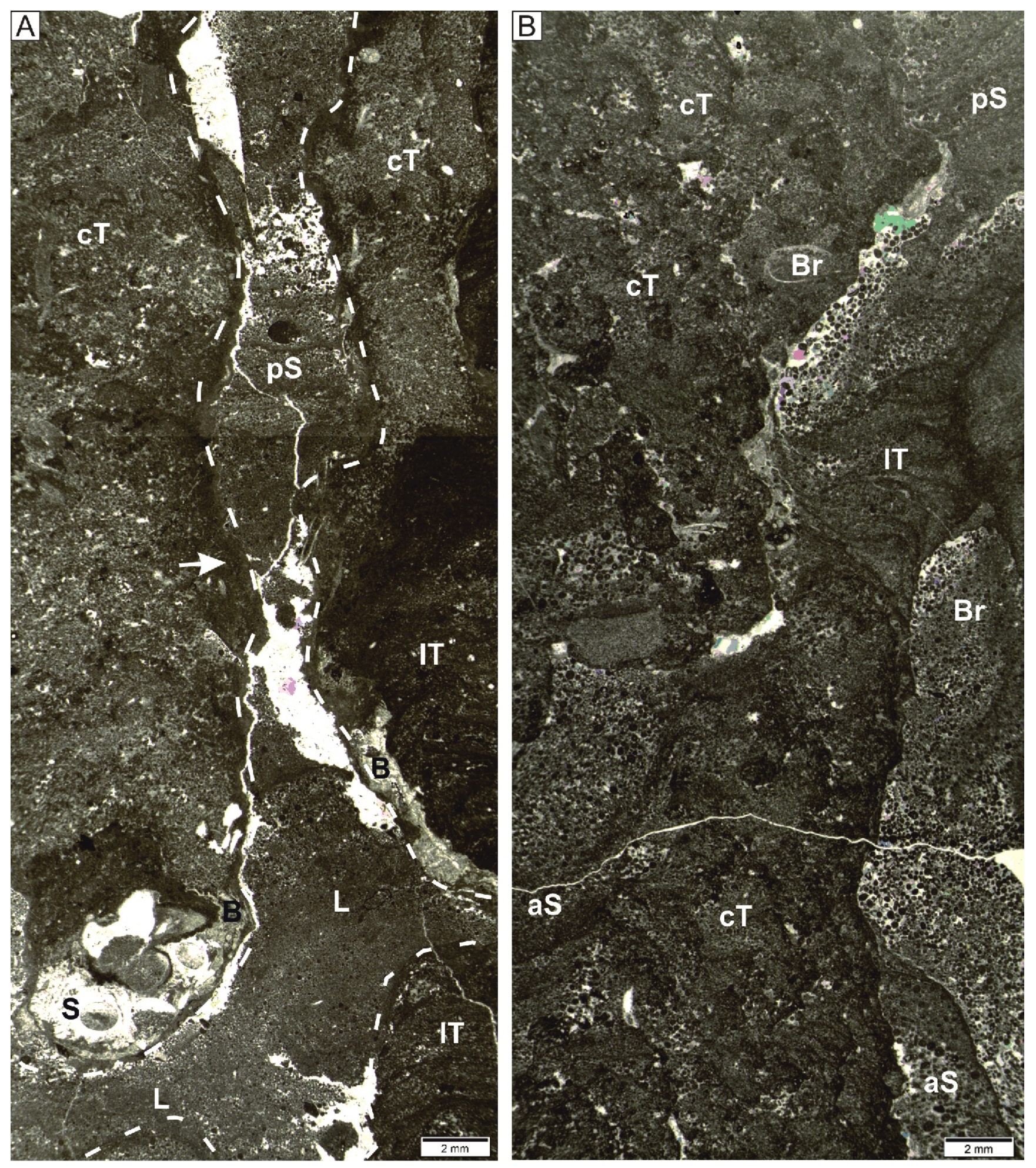

Fig. 8. Microfacies in the Oxfordian reefs from Będkowska Valley

A - thrombolitic bindstone, densely packed clotted (cT) and layered (IT) columns of finger-like thrombolites (dotted lines), among columns of a second microbial generation created by peloidal stromatolite (pS) or peloidal-bioclastic packstone stabilized by leiolites (L), $S$ - serpulids, B - bryozoa, MT III, FT 2, sample SN 22; B - thrombolitic bindstone, in the central part finger-like thrombolite with clotted (cT) and in the upper part layered (IT) texture, between columns of thrombolite thin-grained peloid-bioclastic packstone-grainstone stabilised by peloidal (pS) or agglutinuating (aS) stromatolites, $\mathrm{Br}$ - borings, MT III, FT 2, sample S 11 

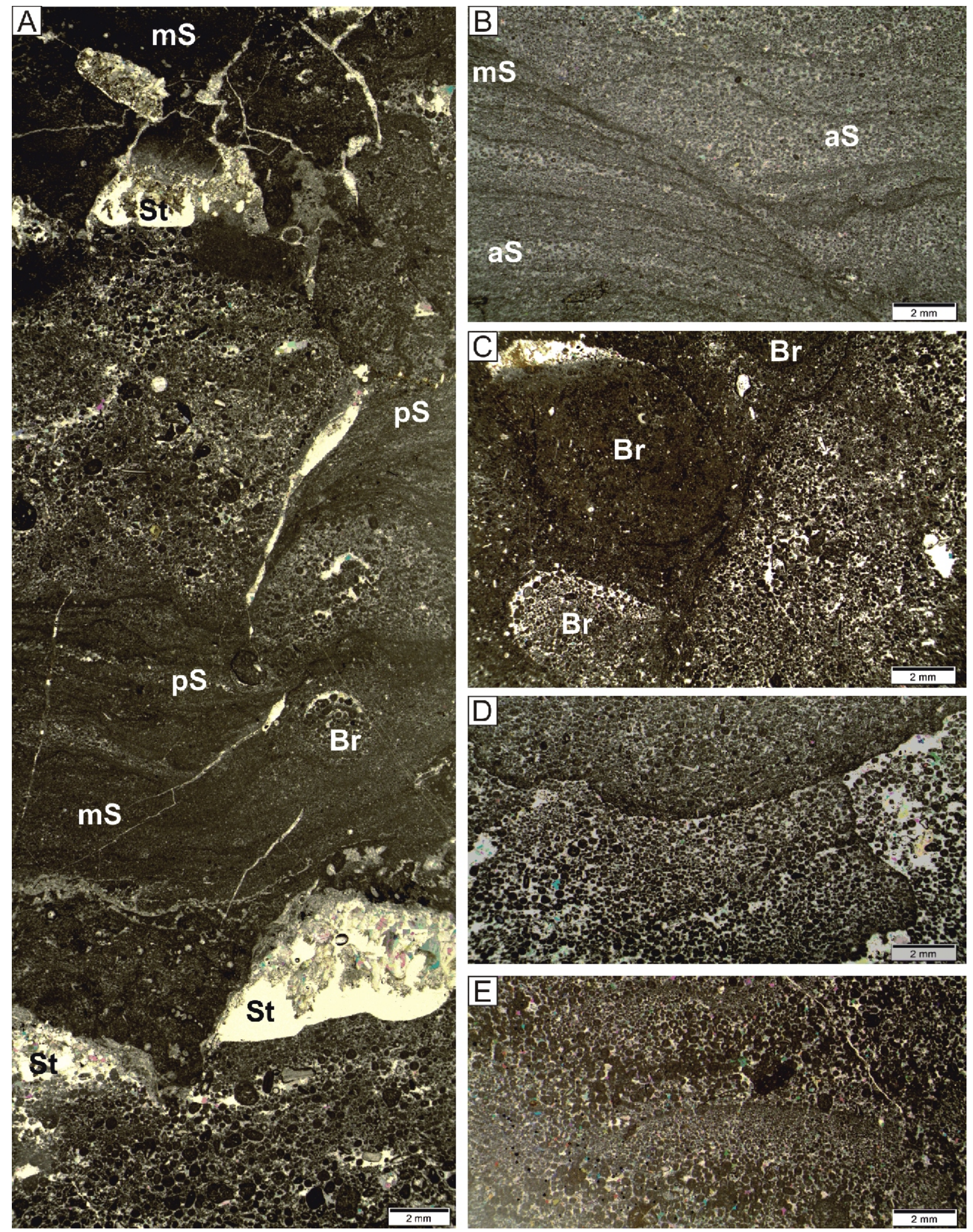

Fig. 9. Microfacies in the Oxfordian reefs from Będkowska Valley

A - stromatolite bindstone (MT IV) and Crescentiella-bioclastic-ooid grainstone-packstone (MT V), St - stromatactis-like cavities, pS - peloidal stromatolite, $\mathrm{mS}$ - micritic stromatolite, $\mathrm{Br}$ - boring, FT 2, sample SS2; B - agglutinuating (aS) and micropeloidal (mS) stromatolite bindstone, two generation of stromatolite with accumulation of peloids and micro-ooids, MT VI, FT 2, sample SS 11; C microbial bindstone, on the left peloidal microbialite with borings $(\mathrm{Br})$, on the right grainstone with ooids, peloids and micro-oncoids, MT VI, FT 2, sample S 3; D - microbial bindstone and ooid-peloid grainstone, MT VII, FT 2, sample S 33; E - ooid-micro-oncoid and peloid grainstone with normal grading stabilized by microbial crusts, MT VII, FT 2, sample SS 15 

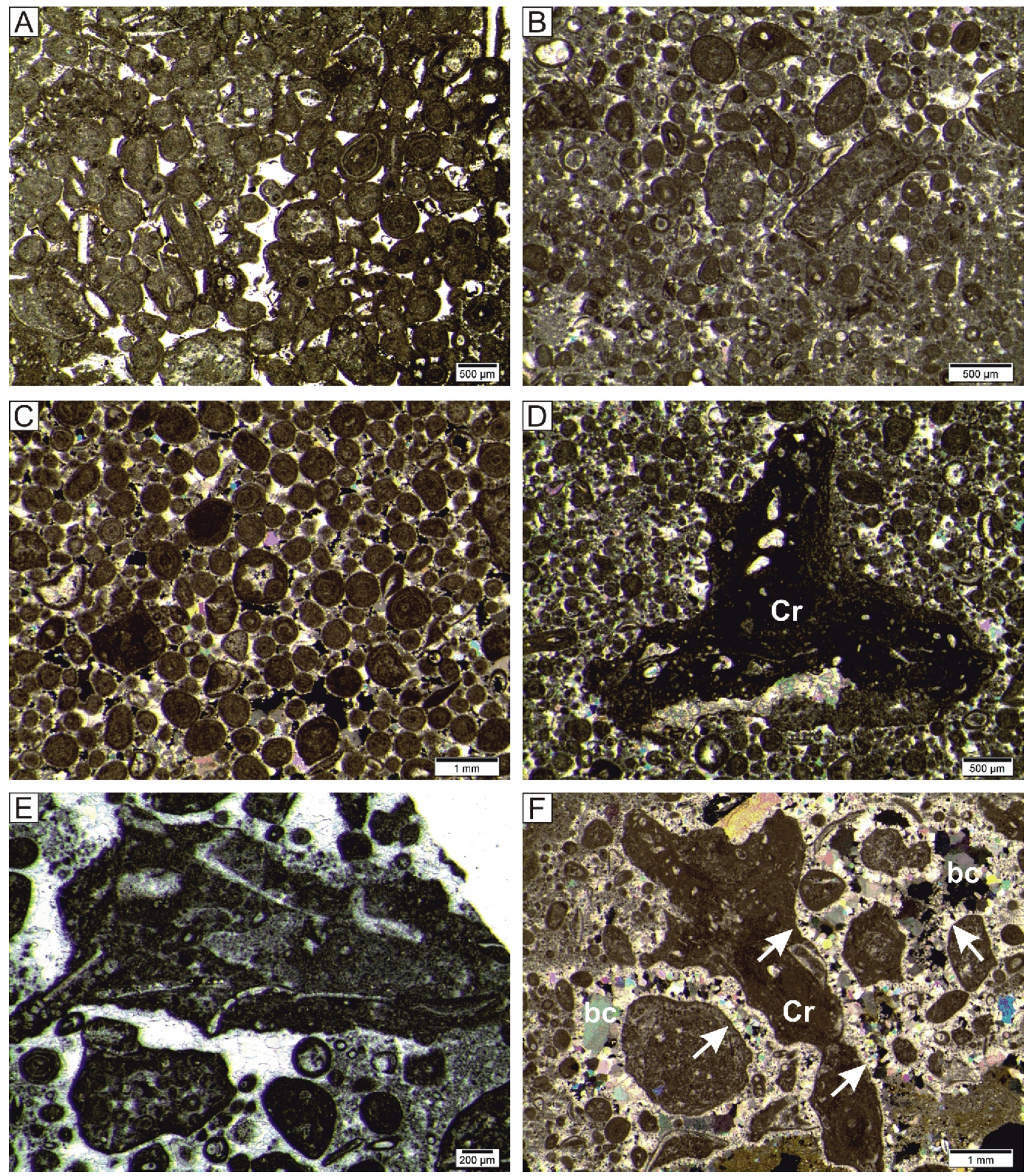

Fig. 10. Microfacies in the Oxfordian reefs from Będkowska Valley

A-C - ooid grainstone with numerous intraclasts, aggregate grains, oncoids and bioclast, MT VIII, FT 3, samples Btu, S 41, SS 17; D Crescentiella morronensis (Cr), ooid-oncoid grainstone; MT VIII, FT 3, sample SS 14; E - ooid-bioclast grainstone with calcareous green algae Campbelliella striata, MT VIII, FT 3, sample SS 44; F - intraclast-ooid rudstone with Crescentiella morronensis (Cr), multiple cement generations are visible, the first generation of cement is represented by a fine rim of radiaxial-fibrous cement (arrows) surrounding Crescentiella, voids and grains followed by blocky cement (bc), MT VIII, FT 3, sample K 9 

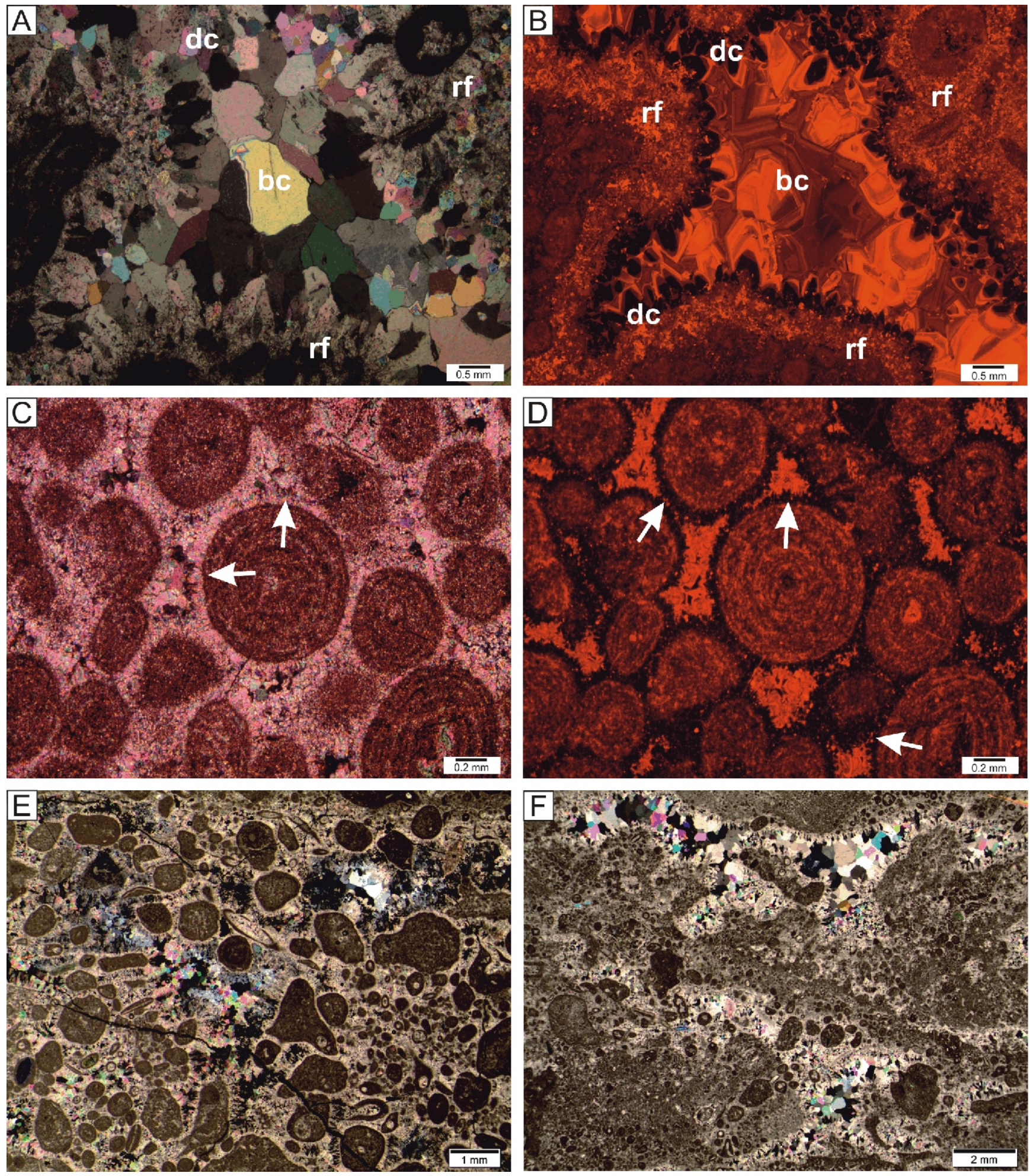

Fig. 11. Microfacies in the Oxfordian reefs from Będkowska Valley

A, B - crossed polars (A) and CL image (B) of the void filled with different generation of cements, the chronological order of cementation is highlighted by cathodoluminescence, radiaxial-fibrous cement (rf) is covered with non-luminescent, marine, phreatic dogtooth cement (dc) which shows red luminescence only in the outer zones of crystals; the centre of the void is filled with blocky cement (bc), MT VII, FT 3, sample SS 11; C, D - crossed polars (C) and CL image (D) of the ooid grainstone with chronological order of cementation highlighted by cathodoluminescence, radiaxial-fibrous cement around ooids (arrows), MT VIII, FT 3, sample S 33; E - intraclast-oncoid-ooid rudstone, in the central part, the voids which are filled with granular quartz, MT VII, FT 3, sample SS 9; F - microbial ooid-bearing bindstone with voids filled by multiple generations of cements, MT VII, FT 3, sample K 3 
Crescentiella (an enigmatic microencruster; formerly Tubiphytes; see Senowbari-Daryan et al., 2008) and bioclasts cemented by structureless microbial crusts forming characteristic connections between the finger-like thrombolites (Fig. 8A). The thrombolites constitute an initial phase of microbialite development and commonly grade upwards into stratiform peloidal stromatolites representing the MT IV microfacies (Fig. 8B). Detrital components in the stromatolites (MT IV type) comprise small bioclasts, peloids, Crescentiella and micritic ooids (Figs. 6C and 9A). At the MT IV/MT V boundary, beneath the micritic and peloidal stromatolites, stromatactis-like cavities (sensu Matyszkiewicz, 1997) occur (Figs. 6C and 9A). These structures reach $2.5 \mathrm{~cm}$ in length and are up to $1.5 \mathrm{~cm}$ high. In their lower parts, the cavities contain internal sediments, followed by calcite cement (Fig. 9A). The internal sediments are grainstones with ooids, up to $0.5 \mathrm{~mm}$ across, and single oncoids and bioclasts (Fig. 9A). The MT IV, MT V and MT VI microfacies types form numerous, repetitive, decimetre-thick units (Figs. 4, 6C and 9A). The MT V microfacies is formed by small ooids (up to $0.5 \mathrm{~mm}$ across), bioclasts, bryozoans and very abundant, individual asesemblages of individual or, rarely, colonial Crescentiella (Krajewski, 2000) in which the individual forms are often connected with microbial crusts (Fig. 9A). The MT VI microfacies comprises agglutinated, microooid-bearing stromatolite-bindstone (Fig. 9B). The stromatolites are commonly wavy and discontinuous (Fig. 9B). Apart from ooids, up to $0.6 \mathrm{~mm}$ in diameter, fine bioclasts, peloids, intraclasts and oncoids are present, accompanied by abundant bioclasts, brachiopods, gastropods, bivalves, calcified sclerosponges and echinoderms. Some ooids are micritized and their internal structure is blurred.

Facies interpretation: limestone with numerous Crescentiella was included in the Tubiphytes-Terebella association (e.g., Leinfelder et al., 1996). Such an association is common in a mid-ramp setting (e.g., Leinfelder et al., 1996; Krajewski et al., 2016). Such sediments were common in many parts of Late Jurassic, open marine, shallow-water, epicontinental environments of the Tethyan Realm (e.g., Leinfelder et al., 1996; Matyszkiewicz, 1997; Krajewski and Olszewska, 2006; Senowbari-Daryan et al., 2008; Hoffmann et al., 2017; Pleş et al., 2017; Krajewski and Schlagintweit, 2018; and references therein). FT 2 is a transitional facies between mid-ramp and inner-ramp facies. Common grainstone in this facies type indicates reworking of material close to wave base. The non-skeletal components of FT 2, including oncoids and ooids, indicate an environment close to the fair-weather wave base. The presence of phototrophic microbialites and Crescentiella in thick, massive limestone indicates palaeodepths above storm-wave base, i.e., around 40-60 m (e.g., Keupp et al., 1993; Aurell et al., 1995; Leinfelder et al., 1996; Matyszkiewicz, 1997; Krajewski et al., 2011, 2016).

FT 3: ooid-intraclastic-bioclastic facies. The FT 3 facies consists of cyclic microbial ooid-bearing bindstone (MT VII) and ooid-intraclast-bioclast grainstone-rudstone (MT VIII) microfacies with thickness ranging from tens of centimetres to several metres (Figs. 4 and 6D-F). The boundaries between MT VII and MT VIII microfacies are fuzzy and the main difference between both types is the presence of agglutinating stromatolites and microbial crusts in MT VII (Fig. 9D, E). Numerous voids are filled with different types of calcite cement (Fig. 11A, B, F). The walls of the cavities are covered with radiaxial fibrous cement, up to $0.02 \mathrm{~mm}$ thick, whereas the central parts are filled with dogtooth and blocky cement types with crystals up to $1.1 \mathrm{~mm}$ across. This facies type is dominated by grainstone-rudstone with various non-skeletal grains: ooids, oncoids (types I and II sensu Védrine et al., 2007), aggregate grains, peloids and intraclasts (Figs. 10 and 11). Common radiaxial fibrous cement developed around ooids and intraclasts (Figs. 10 and $11 \mathrm{C}-\mathrm{F}$ ). Well-sorted ooids with thin-laminated, fine-radial cortices, up to $0.7 \mathrm{~mm}$ across, are dominant (Figs. 10A, C and 11C). The peloids are mostly irregular and up to $0.1 \mathrm{~mm}$ in diameter (Figs. $10 \mathrm{~B}$ and $11 \mathrm{E}$ ). The intraclasts are also irregular and reach up to $5 \mathrm{~mm}$ across (Fig. 10B). The oncoids are up to $1.5 \mathrm{~mm}$ in diameter and show irregular micritic laminae (Figs. 10B and 11E). Aggregate grains composed of ooids, peloids and bioclasts are abundant (Fig. 10C). The skeletal grains comprise poorly rounded fragments of calcareous sclerosponges together with fragments of echinoderms and bryozoans. The FT 3 facies also contains bivalve shells, echinoderms, gastropods and Crescentiella (Fig. 10D, F). Among the bioclasts, reworked calcareous dasycladalean algae Campbelliella striata (Carozzi) (Fig. 10E), ?Salpingoporella sp. or Clypeina sp. (I. Bucur, pers. com., 2018) were identified.

Facies interpretation: the FT 3 facies represents a mid-inner ramp setting, in which non-skeletal components were predominant (e.g., Bádenas and Aurell, 2010). The oolitic grainstone is interpreted as deposited in normal marine shallow-water within the range of normal wave base (e.g., Flügel, 2004). The oolitic-bioclastic grainstone was deposited in a moderate- to high energy environment. The presence of reworked calcareous green algae derived from the platform margin or the inner ramp may suggest the presence of middle ramp settings (e.g., Flügel, 2004; I. Bucur, pers. com., 2018). Types I and II of oncoids (Védrine et al., 2007) also suggest open marine mid-inner ramp deposition environment with moderate to high water energy.

\section{DISCUSSION}

Late Jurassic sedimentation in the broad Polish sector of the Tethys shelf is usually interpreted in terms of the carbonate ramp model, the morphology of which was periodically deformed by synsedimentary tectonic events (e.g., Kutek, 1994; Matyszkiewicz, 1997; Gutowski et al., 2005; Krajewski et al., 2016). The reconstruction of facies distribution on carbonate ramps is complicated due to their vast lateral extent and the lack of recent analogues (e.g., Burchette and Wright, 1992; Pomar, 2001; Olóriz et al., 2003; Bádenas and Aurell, 2010; Colombié et al., 2014). Moreover, the knowledge of factors controlling deposition on carbonate ramps is still insufficient. Numerous publications about the Oxfordian microbial-sponge reefs (including sponge bioherms, spongiolitic mud mounds, microbial mounds, etc.) located on the northern Tethys shelf deal mostly with characterization of skeletal and non-skeletal components (including microbialite types), classifications of the reefs and interpretation of the sedimentary environments (e.g., Gwiner, 1976; Gaillard, 1983; Keupp et al., 1993; Leinfelder et al., 1994, 1996; Koch et al., 1994; Hammes, 1995; Schmid, 1996; Matyszkiewicz, 1997; Schmid et al., 2001; Reolid and Gaillard, 2007; Matyszkiewicz et al., 2006a, 2012). Over the broad, northern Tethys shelf of Western and Central Europe, the microbial-sponge reefs form a wide belt of complexes of massive facies (e.g., Leinfelder et al., 1996, 2002 and references therein). Among bioconstructions, the most common are: (1) coral reefs, (2) sponge reefs, (3) microbial reefs and (4) their combinations, as e.g. sponge-microbial reefs, microbial-sponge reefs or coral-siliceous sponge reefs (e.g., Roniewicz and Roniewicz, 1971; Leinfelder et al., 1996, 2002; Insalaco et al., 1997; Matyszkiewicz, 1997; Schmid et al., 2001; Dupraz and Strasser, 2002; Olivier et al., 2003; Reolid et al., 2005). Among microbialites, many types of 
stromatolites, thrombolites and leiolites have been identified (e.g., Schmid, 1996; Riding, 2000; Schmid et al., 2001; Reolid et al., 2005; Matyszkiewicz et al., 2012). Due to the seemingly monotonous facies development observed in the characteristic vertical white cliffs of difficult access, making macroscopic observations difficult, the vertical sedimentary succession of the reefs in the German-Polish Subprovince (e.g., Ziegler, 1990) has been rarely studied up to now (e.g., Koch et al., 1994 Matyszkiewicz and Krajewski, 1996; Krajewski, 2000; Matyszkiewicz et al., 2006a).

Among the many white cliffs of Upper Jurassic massive facies known from the KCU, the sedimentary sequence of the Sokolica Rock provides the best documentation of the main development phase of the Oxfordian reefs (Figs. 2 and 5). The growth of carbonate buildups attained its climax at the end of the Middle Oxfordian (upper Transversarium Zone) and mainly in the Late Oxfordian (Bifurcatus Zone), possibly due to the Middle Oxfordian (Transversarium Zone) climate warming and sea level rise (e.g., Colombié et al., 2014; Wierzbowski, 2015) which initiated intensive development of carbonate platforms across many European areas on the northern Tethys shelf (e.g., Kutek, 1994; Leinfelder et al., 1994, 1996; Matyszkiewicz, 1997; Olóriz et al., 2003; Bádenas and Aurell, 2010; Colombié et al., 2014; Krajewski et al., 2016; Zuo et al., 2018). The Sokolica Rock is a fragment of a huge reef complex located in the southern part of the KCU, which includes both the massive facies and the thick-bedded biostromal facies. The massive limestones from the southern part of the KCU resemble the massive limestones from southern Germany (e.g., Koch et al. 1994; Leinfelder and Keupp, 1995; Leinfelder et al., 1996 Matyszkiewicz, 1997). Some of them are composed predominantly of peloidal-lithoclast-ooid sand facies (up to 70\%). According to Koch et al. (1994), the spatial distribution of the reefs in relation to the sand facies was probably controlled by hydrodynamic conditions. Similar conclusions were presented after preliminary studies of the Sokolica Rock (Krajewski, 2000). However, our research leads to the conclusion that such interpretations result from incomplete sampling of seemingly monotonous facies, which hinders the interpretation of vertical and lateral facies distribution. Studies of several parallel profiles in the exposure of the Sokolica Rock disclosed that both the microbial-sponge reef (FT 1) and the detrital facies (FT 2 and FT 3) form characteristic stratigraphic intervals (Fig. 5). The binding of grains by microbialites and the early cementation caused strong lithification of the intervals dominated by non-skeletal grains (FT 2 and FT 3), which, together with the intervals rich in calcified siliceous sponges (FT 1) constitute the massive facies seen as a monolithic rock complex. Macroscopically, the FT 2 and FT 3 facies types are more lithified and less porous in comparison with the FT 1 facies, and siliceous sponges are minor components.

The facies and microfacies as well as their vertical succession document several developmental stages of carbonate buildup of the Sokolica Rock, suggesting cyclic changes of the depositional environment, presumably corresponding to transgressive-regressive sequences in the Polish part of a broad, ramp-type carbonate platform (e.g., Gutowski et al., 2005; Krajewski et al., 2016). By contrast with common opinion, the siliceous sponges were dominant reef builders only in some parts of the reefs. Instead, the massive facies was produced mostly by various microbialites and non-skeletal grains (e.g., Matyszkiewicz, 1997; Matyszkiewicz et al., 2006a, 2012). The succession types $A$ (STA) and B (STB) distinguished document the reef evolution. The STA formed by microbial-sponge reefs (FT 1 facies) does not show significant lithological variability. At the initial growth stage, the carbonate buildups were metre-scale, sponge-microbial spaced and cluster reefs, which evolved into microbial-sponge filled-frame reefs with a well-developed rigid framework (e.g., Trammer, 1982; Matyszkiewicz, 1997; Matyszkiewicz et al., 2012). On the ramp, carbonate buildups composed of the FT 1 facies formed broad but rather low-relief reef complexes, up to some tens of metres thick (e.g., Leinfelder et al., 1994, 1996; Matyszkiewicz, 1997; Schmid et al., 2001). On the Sokolica reef, their development can be observed in three stratigraphic intervals. The monotonous but intense growth of microbial-sponge reefs (FT 1 facies) proceeded under relatively stable environmental conditions related to reduced allochthonous deposition probably controlled by sea level rise. Their growth ceased with the general shallowing trend documented, for example, by the breccia levels (Fig. 5) and intense redeposition of shallow-water non-skeletal grains.

The microbial-sponge FT 1 facies was overlain by sediments composed mostly of highly diverse microbialites and non-skeletal grains (FT 2 and FT 3 facies). These sediments form mainly dm-scale successions of type B (STB) built of the MT IV-VIII microfacies and resulting from lower rank sea level changes. Common redeposition of non-skeletal grains together with a greater or lesser share of specific grains may indicate evolutionary stages of platform development, related to e.g. flooding, aggradational growth of the reefs and progradation of the platform (e.g., Flügel, 2004; Bádenas and Aurell, 2010). Compositional variability of non-skeletal grains and cyclicity of sequences result from sea level fluctuations which controlled sediment production on the platform and intensity of shedding (e.g., Flügel, 2004).

The FT 2 facies appeared when the supply of allochthonous material increased slightly and the redeposited sediments were stabilized by microbialites. Variability of the content of non-skeletal grains and the development of microbialites were controlled mostly by changing hydrodynamic conditions and by redeposition of sediments as well as by the local morphology of the platform. These factors were responsible for diverse successions, development and thickness of both the FT 2 and FT 3 facies on various parts of the platform. Moreover, this diversity is difficult to observe due to the massive structure of the limestones in the KCU.

The most important role in the KCU reef construction was played by microbialites, which are interpreted as products of organomineralization, i.e. microbially-induced and microbially-influenced mineralization (e.g., Webb, 1996; Riding, 2000; Dupraz et al., 2009; Reolid, 2011 and references therein). The development of microbialites was controlled by: (1) background sedimentation rate, (2) ground water seepage, (3) synsedimentary tectonics, (4) energy of environment and (5) influx of nutrients (Reitner et al., 1995; Leinfelder et al., 1996; Riding, 2000; Dupraz and Strasser, 2002; Olivier et al., 2003; Reolid et al., 2005; Matyszkiewicz et al., 2012). In the Sokolica reef succession, the microbialites are very diverse, as across the whole KCU area. Microbialites from the Kraków area (particularly the relation of their fabric to various palaeosettings) were studied in detail by Matyszkiewicz et al. (2012) who found negative $\mathrm{Ce}$ anomalies together with a distinct enrichment in heavy REE in all the microbialites studied and concluded that during the Oxfordian the seawater covering the carbonate platform in the Kraków area was well oxygenated and that its alkalinity was comparable to that of recent marine environments. The diverse development of microbialites was controlled by local sedimentary conditions and remained unaffected by changes in the seawater chemistry. The succession of facies types and the varying thickness of particular microfacies types on the Sokolica Rock show that the principal factors controlling the growth of microbialites were water energy and accumula- 
tion rate, both dependent on local sedimentary conditions, as indicated by the observations of Matyszkiewicz et al. (2012).

In the two stratigraphic intervals of the Sokolica reef, the sediment is dominated by shallow-water, non-skeletal grains and contains only minor amounts of metazoans. Based on the distribution of non-skeletal grains on a Kimmeridgian carbonate ramp, Bádenas and Aurell (2010) constructed three models: (1) low-energy, peloidal-dominated, (2) intermittent, high-energy, ooid-dominated and (3) high-energy, ooid/oncoid-dominated. The prevalence of the non-skeletal grains building the shoal facies was controlled mainly by hydrodynamic conditions. Considering their development and main components, the stratigraphic intervals dominated by non-skeletal grains, which were observed in the FT 3 facies, resemble the diversity of non-skeletal grains and the models of the ooid-dominated, mid-ramp foreshoal facies and inner-ramp shoal facies (cf. Bádenas and Aurell, 2010). The shoals were covered by thinly-laminated, radial ooids (type- 3 ooids), which indicate normal-marine shallow-waters and intermittent high-energy conditions (Strasser, 1986; Bádenas and Aurell, 2010). During periods of low deposition rate, these sediments were stabilized by microbialites. The presence of both type-I and type-II oncoids (Védrine et al., 2007) points to relatively high-energy conditions enabling the rolling of oncoids. The prevalence of a given type of non-skeletal grains on the mid-inner ramp was mainly an effect of hydrodynamic conditions. The abundance of reworked peloids in shallower settings can be linked to relatively low-energy conditions (e.g., Flügel, 2004; Bádenas and Aurell, 2010). With the shallowing of the platform, the sediment became dominated by type-3 ooids produced in the foreshoal environment under intermittent high-energy conditions.

\section{CONCLUSIONS}

The sedimentary succession of the Sokolica Rock massive limestone from Będkowska Valley represents the largest example of an Upper Oxfordian reef located in the southern part of the Kraków-Częstochowa Upland. This reef represents the maximum development of Upper Jurassic reefs in the Polish sector of the northern Tethys shelf, corresponding to the upper Transversarium and Bifurcatus zones. It is followed by drowning of the carbonate platform in the lower Bimmamatum Zone, expressed by bedded marly limestones and marls.

The reef succession comprises three types of facies, in which eight most important microfacies types were distingushed. Their vertical succession documents several developmental stages indicating cyclic changes of the depositional environment of the Upper Oxfordian reefs corresponding to sea level changes in the Polish part of the broad, ramp-type carbonate platform. The mid-ramp, mainly microbial-sponge frame-reefs represent a transgressive, monotonous depositional sequence. Thicknesses of the microbial-sponge facies (STA) vary from several to a dozen metres. At the initial growth stage, the carbonate buildups were metre-scale, sponge-microbial spaced and cluster reefs, which evolved into microbial-sponge filled-frame reefs with a well-developed rigid framework. On the ramp, the carbonate buildups composed mainly of microbial-sponge facies formed broad but rather low-relief reef complexes. The monotonous but intense growth of microbial-sponge facies proceded under relatively stable environmental conditions related to reduced allochthonous deposition probably controlled by sea level rise.

The microbial-Crescentiella-ooid and ooid-intraclast-bioclast facies (STB) form numerous mid-inner ramp dm-scale sedimentary successions corresponding to higher-order sea level changes. This stage of reef evolution was dominated by non-skeletal grains, mainly ooids, oncoids, aggregate grains, bioclasts and intraclasts. The non-skeletal grains were stabilized by microbialites and were subjected to early cementation, which created the grain-dominated, non-skeletal grain-microbial cement-supported reefs.

Acknowledgements. The authors are grateful to the three reviewers, A. Strasser, G. Pleş and Anonymous as well as the editor T.M. Peryt for their constructive comments and suggestions that considerably improved this paper. We would like to thank I. Bucur for the help in identification of the algae. The research was financed from the AGH-UST Grant Nos. 11.11.140.626.

\section{REFERENCES}

Aurell, M., Bosence, D., Waltham, D.A., 1995. Carbonate ramp depositional systems from a Late Jurassic epeiric platform (lberian basin, Spain): a combined computer modelling and outcrop analysis. Sedimentology, 42: 75-94.

Allenbach, R.P., 2002. The ups and downs of 'Tectonic Quiescence' - recognizing differential subsidence in the epicontinental sea in the Oxfordian in the Swiss Jura Mountains. Sedimentary Geology, 150: 323-342.

Barski, M., Mieszkowski, R., 2014. Upper Jurassic large-scale debris flow deposits in interbiohermal basins of the sponge megafacies in Poland - new in sights. Neues Jahrbuch für Geologie und Paläontologie Abhandlungen, 272: 47-59.

Bádenas, B., Aurell, M., 2010. Facies models of a shallow-water carbonate ramp based on distribution of non-skeletal grains (Kimmeridgian, Spain). Facies, 56: 89-110.

Brachaniec, T., Salamon, M.A., Szopa, K., Gedl, P., Brom, K.R., Leśko, K., 2016. Origin of Jurassic-Cretaceous neptunian dikes from the Cracow-Częstochowa Upland in southern Poland. Geobios, 49: 155-165.
Burchette, T.P., Wright, V.P., 1992. Carbonate ramp depositional systems. Sedimentary Geology, 79: 3-57.

Colombié, C., Giraud, F., Schnyder, J., Götz., A.E., Boussaha, M., Aurell, M., Bádenas, B., 2014. Timing of sea level, tectonics and climate events during the uppermost Oxfordian (Planula zone) on the Iberian ramp (northeast Spain). Palaeogeography, Palaeoclimatology, Palaeoecology, 412: 17-31.

Dupraz, C., Strasser, A., 1999. Microbialites and micro-encrusters in shallow coral bioherms (Middle to Late Oxfordian, Swiss Jura Mountains). Facies, 40: 101-130.

Dupraz, C., Strasser, A., 2002. Nutritional modes in coral-microbialite reef (Jurassic, Oxfordian, Switzerland): evolution of trophic structure as response to environmental change. Palaios, 17: 449-471.

Dupraz, C., Reid, R.P., Braissant, O., Decho, A.W., Norman, R.S., Visscher, P.T., 2009. Processes of carbonate precipitation in modern microbial mats. Earth-Science Reviews, 96: 141-162. 
Dżułyński, S., 1952. The origin of the Upper Jurassic limestones in the Cracow area. Rocznik Polskiego Towarzystwa Geologicznego, 21: 125-180.

Flügel, E., 2004. Microfacies of Carbonate Rocks, Analysis, Interpretation and Application. Springer, Berlin.

Gaillard, C., 1983. Les biohermes à spongiaires et leur environment dans l'Oxfordian du Jura meridional. Documents des Laboratoires de Géologie de la Faculté des Sciences de Lyon, 90: 1-515.

Głowniak, E., 2006. The Platysphinctes immigration event: biostratigraphic and paleobiogeographic implications for the Middle Oxfordian (Late Jurassic) seas of Central Europe (MW Germany and Poland). Neues Jahrbuch für Geologie und Paläontologie Abhandlungen, 241: 155-201.

Gutowski, J., Popadyuk, I.V., Olszewska, B., 2005. Late Jurassic-earliest Cretaceous evolution of the epicontinental sedimentary basin of southeastern Poland and Western Ukraine. Geological Quarterly, 49 (1): 31-44.

Gwinner, M.P., 1976. Origin of the Upper Jurassic Limestones of the Swabian Alb (Southwest Germany). Contributions to Sedimentology, 5: 1-76.

Hammes, U., 1995. Initiation and development of small-scale sponge mudmounds, Late Jurassic, southern Franconian Alb, Germany. IAS Special Publication, 23: 335-357.

Harańczyk, C., Lankosz, M., Wolska, A., 1995. Granodiorite of Jerzmanowice porphyries and $\mathrm{Cu}-$ Mo ores (in Polish with English summary). Rudy Metale, 40: 334-341.

Helm, C., Schülke, I., 1998. A coral-microbialite path-reef from the Late Jurassic (florigemma-Bank, Oxfordian) of NW Germany (Süntel Mountains). Facies, 39: 75-104.

Hoffmann, M., Kołodziej, B., Skupien, P., 2017. Microencrustermicrobial framework and synsedimentary cements in the Štramberk Limestone (Carpathians, Czech Republic): Insights into reef zonation. Annales Societatis Geologorum Poloniae, 87: $325-347$.

Insalaco, E., Hallam, A., Rosen, B., 1997. Oxfordian (Upper Jurassic) coral reefs in Western Europe: reef types and conceptual depositional model. Sedimentology, 44: 707-734.

Jędrys, J., Krajewski, M., 2007. Wykształcenie i rozwój górnojurajskich osadów okolic Bębła na tle budowy podmezozoicznego podłoża, Wyżyna Krakowska (in Polish). Tomy Jurajskie, 4: 95-102.

Jurkowska, A., Kołodziej, B., 2013. Taphonomic differentiation of Oxfordian ammonites from the Cracow Upland, Poland Paläontologische Zeitschrift, 87: 67-82.

Kaya, M.Y., Altiner, D., 2014. Terebella lapilloides Munster, 1833 from the Upper Jurassic-Lower Cretaceous Inalti carbonates, northern Turkey: its taxonomic position and paleoenvironmental-paleoecological significance. Turkish Journal of Earth Science, 23: 166-183.

Keupp, H., Jenisch, A., Herrmann, R., Neuweiler, F., Reitner, J., 1993. Microbial carbonate crust: a key to the environmental analysis of fossil spongiolites? Facies, 29: 41-54.

Koch, R., Senowbari-Daryan, B., Strauss, H., 1994. The Late Jurassic 'Massenkalk Fazies' of Southern Germany; calcareous sand piles rather than organic reefs. Facies, 31: 179-208.

Kochman, A., Matyszkiewicz, J., 2013. Experimental method for esti mation of compaction in the Oxfordian bedded limestones of the southern Kraków-Częstochowa Upland, Southern Poland. Acta Geologica Polonica, 63: 681-696.

Krajewski, M., 2000. Lithology and morphology of Upper Jurassic carbonate buildups in the Będkowska Valley, Kraków region Southern Poland. Annales Societatis Geologorum Poloniae, 70 : 51-163.

Krajewski, M., Matyszkiewicz, J., 2004. Development and facial architecture of the Upper Jurassic complexes of buildups in the SW part of the Kraków Upland (in Polish with English summary) (ed. J. Partyka): The diversification and transformation of natural and cultural environment of the Kraków Częstochowa Upland, 1: 27-34. Ojców National Park. Ojców.

Krajewski, M., Olszewska, B., 2006. New data about microfacies and stratigraphy of the Late Jurassic Aj-Petri carbonate buildup
(SW Crimea Mountains, S Ukraine). Neues Jahrbuch für Geologie und Paläontologie Monatschefte, (5): 298-312.

Krajewski, M., Schlagintweit, B., 2018. Crescentiella-microbial-cement microframeworks in the Upper Jurassic reefs of the Crimean Peninsula. Facies, 64: 21.

Krajewski, M., Matyszkiewicz, J., Król, K., Olszewska, B., 2011 Facies of the Upper Jurassic-Lower Cretaceous deposits from the southern part of the Carpathian Foredeep basement in the Kraków-Rzeszów area (southern Poland). Annales Societatis Geologorum Poloniae, 81: 269-290.

Krajewski, M., Olchowy, P., Felisiak, I., $2014 . \quad$ Lower Kimmeridgian layer with bored and encrusted hiatus concretions (Upper Jurassic, Central Poland): implications for stratigraphy and basin evolution. Annales Societatis Geologorum Poloniae, 84: 113-129.

Krajewski, M., Olchowy, P., Felisiak, I., 2016. Late Jurassic facies architecturevof the Złoczew Graben: implications for evolution of the tectonic-controlled northern peri-Tethyan shelf (Upper Oxfordian-Lower Kimmeridgian, Poland). Facies, 62: 4.

Krajewski, M., Olchowy, P., Zatoń, M., Bajda, T., 2017 Kimmeridgian hardground-sequence boundary from the Mesozoic margin of the Holy Cross Mountains (central Poland): implications for the evolution of the northern Tethyan carbonate Shelf. Facies, 63: 15

Król, K., 2004. Depositional environment of the Upper Jurassic carbonate deposits of the Carpathians Foreland (Słupiec-Pacanów region) (in Polish with English summary). Kwartalnik AGH, Geologia, 30: 349-387.

Kutek, J., 1994. Jurassic tectonic events in south-eastern Poland. Acta Geologica Polonica, 44: 167-221.

Leinfelder, R.R., Keupp, H., 1995. Upper Jurassic mud mounds: allochthonous sedimentation versus autochthonous carbonate production. Facies, 32: 1-70.

Leinfelder, R.R., Krautter, M., Laternser, R., Nose, M., Schmid, D.U., Schweigert, G., Werner, W., Keupp, H., Brugger, H., Herrmann, R., Rehfeld-Kiefer, U., Schroeder, J.H., Reinhold, C., Koch, R., Zeiss, A., Schweizer, V., Christmann, H., Menges, G., Luterbacher, H., 1994. The origin of Jurassic reefs: current research developments and results. Facies, 31: $1-56$.

Leinfelder, R.R., Werner, W., Nose, M., Schmid, D.U., Krautter, M., Laternser, R., Takacs, M., Hartmann, D., 1996. Paleoecology, growth parameters and dynamics of coral, sponge and microbolite reefs from the Late Jurassic. Göttinger Arbeiten zur Geologie and Paläontologie, Sb 2: 227-248.

Leinfelder, R.R., Schmid, D.U., Nose, M., Werner, W., 2002. Jurassic reef patterns-the expression of a changing globe. SEPM Special Publications, 72: 465-520.

Matyja, B.A., 2009. Development of the Mid-Polish Trough versus Late Jurassic evolution in the Carpathian Foredeep area. Geological Quarterly, 53 (1): 49-62.

Matyja, B.A., Tarkowski, R., 1981. Lower and Middle Oxfordian ammonite biostratigraphy at Zalas in the Cracow Upland. Acta Geologica Polonica, 31: 1-14

Matyja, B.A., Gutowski, J., Wierzbowski, A., 1989. The open shelfcarbonate platform succession at the Oxfordian/Kimmeridgian boundary in the SW margin of the Holy Cross Mts: stratigraphy, facies and ecological implications. Acta Geologica Polonica, 39: 29-48.

Matyszkiewicz, J., 1997. Microfacies, sedimentation and some aspects of diagenesis of Upper Jurassic sediments from the elevated part of the Northern peri-Tethyan Shelf: a comparative study on the Lochen area (Schwäbische Alb) and the Cracow area (Cracow Wieluń Upland, Poland). Berliner Geowissenschaftliche Abhandlungen, E21: 1-111.

Matyszkiewicz, J., Felisiak, I., 1992. Microfacies and diagenesis of an Upper Oxfordia carbonate buildup in Mydlniki (Cracow area, Southern Poland). Facies, 27: 179-190.

Matyszkiewicz, J., Krajewski, M., 1996. Lithology and sedimentation of Upper Jurassic massive limestones near Bolechowice, Kraków-Wieluń Upland, south Poland. Annales Societatis Geologorum Poloniae, 66: 201-232. 
Matyszkiewicz, J., Kochman, A., 2016. Pressure dissolution features in Oxfordian microbial-sponge buildups with pseudonodular texture, Kraków Upland, Poland. Annales Societatis Geologorum Poloniae, 86: 355-377.

Matyszkiewicz, J., Krajewski, M., Kędzierski, J., 2006a. Origin and evolution of an Upper Jurassic complex of carbonate buildups from Zegarowe Rocks (Kraków-Wieluń Upland, Poland). Facies, 52: 249-263.

Matyszkiewicz, J., Krajewski, M., Żaba, J., 2006b. Structural control on the distribution of Upper Jurassic carbonates build ups in the Kraków-Wieluń Upland (south Poland). Neues Jahrbuch für Geologie und Paläontologie Monatschefte, 3: 182-192.

Matyszkiewicz, J., Kochman, A., Duś, A., 2012. Influence of local sedimentary conditions on development of microbialites in the Oxfordian carbonate buildups from the southern part of the Kraków-Częstochowa Upland (south Poland). Sedimentary Geology, 263-264: 109-132.

Matyszkiewicz, J., Kochman, A., Rzepa, G., Gołębiowska, B., Krajewski, M., Gajdzik, K., Żaba, J., 2015a. Epigenetic silicification of the Upper Oxfordian limestone in the Sokole Hills (Kraków-Częstochowa Upland): relationship to facies development and tectonics. Acta Geologica Polonica, 65: 181-203.

Matyszkiewicz, J., Felisiak, I., Hoffmann, M., Kochman, A. Kołodziej, B., Krajewski, M., Olchowy, P., 2015b. Transgressive Callovian succession and Oxfordian microbial-sponge carbonate buildups in the Kraków Upland. In: Guide book for Field Trips Accompanying 31st IAS Meeting of Sedimentology Held in Kraków on 22nd-25th of June (ed. G. Haczewski): 51-74. Polskie Towarzystwo Geologiczne.

Matyszkiewicz, J., Krajewski, M., Kochman, A., Kozłowski, A., Duliński, M., 2016. Oxfordian neptunian dykes with brachiopods from the southern part of the Kraków-Częstochowa Upland (southern Poland) and their links to hydrothermal vents. Facies, 62: 12.

Morycowa, E., Moryc, W., 1976. The Upper Jurassic sediments in the Foreland of the Polish Carpathians (Sandomierz Basin) (in Polish with English summary). Rocznik Polskiego Towarzystwa Geologicznego, 46: 231-288.

Nieto, L.M., Reolid, M., Molina, J.M., Ruiz-Ortiz, P.A., JiménezMillán, J., Rey, J., 2012. Evolution of pelagic swells from hardground analysis (Bathonian-Oxfordian, Eastern External Subbetic, southern Spain). Facies, 58: 389-414.

Olchowy, P., 2011. Possible origin of stromatactis-like cavities in Upper Jurassic sediments from the Wielkanoc quarry near Gołcza (Kraków-Częstochowa Upland, southern Poland) - experimental studies. Facies, 57: 613-625.

Olivier, N., Hantzpergue, P., Gaillard, C., Pittet, B., Leinfelder, R.R., Schmid, D.U., Werner, W., 2003. Microbialite morphology, structure and growth: a model of the Upper Jurassic reefs of the Chay Peninsula (western France). Palaeogeography, Palaeoclimatology, Palaeoecology, 193: 383-404.

Olóriz, F., Reolid, M., Rodríguez-Tovarm, F.J., 2003. A Late Jurassic carbonate ramp colonized by sponges and benthic microbia communities (External Prebetic, Southern Spain). Palaios, 18: 428-545.

Pleş, G., Bârtaş, T., Chelaru, R, Bucur, I.I., 2017. Crescentiella morronensis (Crescenti) (incertae sedis) dominated microencruster association in Lower Cretaceous (lower Aptian) limestones from Rarău Massif (Eastern Carpathians, Romania). Cretaceous Research, 79: 91-108.

Pomar, L., 2001. Types of carbonate platforms: a genetic approach. Basin Research, 13: 313-334

Pożaryski, W., Brochwicz-Lewiński, W., Brodowicz, Z., Jaśkowiak-Schoeneichowa, M., Milewicz, J., Sawicki, L., Uberna, T., 1979. Geological map of Poland and adjoining countries without Cenozoic formations 1:1 000000 (in Polish). Geological Institute, Warszawa.

Reitner, J., Neuweiler, F., Gautret, P., 1995. Modern and fossils automicrites: implications for mud mounds genesis. Facies, 32: 4-17.

Reolid, M., 2011. Interactions between microbes and siliceous sponges from Upper Jurassic buildups of External Prebetic (SE Spain). Lecture Notes in Earth Sciences, 131: 343-354.

Reolid, M., Gaillard, Ch., 2007. Microfacies, microtaphonomic traits and foraminiferal assemblages from Upper Jurassic oolitic-coral limestones: stratigraphic fluctuations in a shallowing upward sequence (French Jura, Middle Oxfordian). Facies, 53: 553-574.

Reolid, M., Gaillard, Ch., Olóriz, F., Rodríguez-Tovar, F.J., 2005. Microbial encrustations from the Middle Oxfordian-earliest Kimmeridgian lithofacies in the Prebetic Zone (Betic Cordillera, southern Spain): characterization, distribution and controlling factors. Facies, 50: 529-543.

Riding, R., 2000. Microbial carbonates: the geological record of calcified bacterial-algal mats and biofilms. Sedimentology, 47: 179-214.

Riding, R., 2002. Structure and composition of organic reefs and carbonate mud mounds: concepts and categories. Earth-Science Reviews, 58: 163-231.

Roniewicz, E., Roniewicz, P., 1971. Upper Jurassic coral assemblages of the Central Polish Uplands. Acta Geologica Polonica, 21: 399-424.

Schmid, D.U., 1996. Marine Mikrobolithe und Mikroinkrustierer aus dem Oberjura. Profil, 9: 101-251.

Schmid, D.U., Leinfelder, R.R., Nose, M., 2001. Growth dynamics and ecology of Upper Jurassic mounds, with comparisons to Mid-Palaeozoic mounds. Sedimentary Geology, 145: 343-376.

Senowbari-Daryan, B., Bucur, I.I., Schlagintweit, F., Săsăran, E., Matyszkiewicz, J., 2008. Crescentiella, a new name for "Tubiphytes" morronensis CRESCENTI, 1969: an enigmatic Jurassic-Cretaceous microfossil. Geologia Croatica, 61 $185-214$.

Strasser, A., 1986. Ooids in Purbeck limestones (lowermost Cretaceous) of the Swiss and French Jura. Sedimentology, 33: 711-727.

Trammer, J., 1982. Lower to Middle Oxfordian sponges of the Polish Jura. Acta Geologica Polonica, 32: 1-39.

Trammer, J., 1989. Middle to upper Oxfordian sponges of the Polish Jura. Acta Geologica Polonica, 39: 49-91.

Védrine, S., Strasser, A., Hug, W., 2007. Oncoid growth and distribution controlled by sea-level fluctuations and climate (Late Oxfordian, Swiss Jura Mountains). Facies, 53: 535-552.

Webb, G.E., 1996. Was Phanerozoic reef history controlled by the distribution of non-enzymatically secreted reef carbonates (microbial carbonate and biologically induced cement)? Sedimentology, 43: 947-971.

Wierzbowski, H., 2015. Seawater temperatures and carbon isotope variations in central European basins at the Middle-Late Jurassic transition (Late Callovian-Early Kimmeridgian). Palaeogeography, Palaeoclimatology, Palaeoecology, 440: 506-523.

Wierzbowski, A., 2017. The Lower Kimmeridgian of the Wielun Upland and adjoining regions in central Poland: lithostratigraphy, ammonite stratigraphy (upper Planula/Platynota to Divisum zones), palaeogeography and climate-controlled cycles. Volumina Jurassica, 15: 1-80.

Woźniak, T., Bania, G., Mościcki, W.J.,Ćwiklik, M., 2018. Electrical resistivity tomography (ERT) and sedimentological analysis applied to in vestigation of Upper Jurassic limestones from the Krzeszowice Graben (Kraków Upland, southern Poland). Geological Quarterly, 62 (2): 287-302.

Ziegler, P.A., 1990. Geological Atlas of Western and Central Europe. Shell Internationale Petroleum Maatschapij, The Hauge.

Ziółkowski, P., 2007. Stratygrafia i zróżnicowanie facjalne górnej jury wschodniej części Wyżyny Krakowskiej (in Polish). Tomy Jurajskie, 4: 25-38.

Zuo, F., Heimhofer, U., Huck, S., Luppold, F.W., Wings, O., Erbacher, J., 2018. Sedimentology and depositional sequences of a Kimmeridgian carbonate ramp system, Lower Saxony Basin, Northern Germany. Facies, 64: 1

Żaba, J., 1999. The structural evolution of Lower Paleozoic succession in the Upper Silesia Block and Małopolska Block border zone, southern Poland (in Polish with English summary). Prace Państwowego Instytutu Geologicznego, 166: 1-162.

Żelaźniewicz, A., Aleksandrowski, P., Buła, Z., Karnkowski, P.H., Konon, A., Oszczypko, N., Ślączka, A., Żaba, J,, Żytko, K., 2011. Regionalizacja tektoniczna Polski (in Polish). Komitet Nauk Geologicznych PAN, Wrocław. 